\title{
Two new species of Metacyclops Kiefer, 1927 (Copepoda, Cyclopoida) from Thailand and an up-to-date key to the species recorded in Asia
}

\author{
Sujeephon ATHIBAI ${ }^{\circledR 1}$, Koraon WONGKAMHAENG ${ }^{\circledR 2} \&$ \\ Chaichat BOONYANUSITH ${ }^{\circledR 3, *}$ \\ ${ }^{1}$ Applied Taxonomic Research Center and Department of Biology, Faculty of Science, \\ Khon Kaen University, Khon Kaen 40002, Thailand. \\ ${ }^{2}$ Department of Zoology, Faculty of Science, Kasetsart University, Bangkok 10900, Thailand. \\ ${ }^{3}$ School of Biology, Faculty of Science and Technology, Nakhon Ratchasima Rajabhat University, \\ Nakhon Ratchasima 30000, Thailand. \\ *Corresponding author: chaichat.b@nrru.ac.th \\ 1Email: sujiat@kku.ac.th \\ 2Email: koraon.w@ku.ac.th \\ ${ }^{1}$ urn:lsid:zoobank.org:author:8CAD9425-CB2A-4E7E-A71C-F040194EB4EB \\ ${ }^{2}$ urn:lsid:zoobank.org:author:D34BFAAF-A3F5-47E4-9671-A1F02717D789 \\ ${ }^{3}$ urn:lsid:zoobank.org:author:EB363F4D-60CB-4431-BF5D-1000E3E01F8B
}

\begin{abstract}
Metacyclops sakaeratensis sp. nov. and M. brancelji sp. nov. are described as being present in the mountainous areas of Northeastern and Southern Thailand, respectively. Two new species resemble M. woni in both sexes, but they are easily distinguished from their Cambodian relative by having: 1) transverse suture on the dorsal surface of the genital double-somite, 2) serrated hyaline frill on the posterior margin of third pedigerous somite, 3 ) different length/width ratio of caudal ramus, and 4) a row of spinule on caudal surface of intercoxal sclerite of the third swimming legs. The significant differences between $M$. sakaeratensis sp. nov. and M. brancelji sp. nov. are present in both sexes, including the body size, integumental ornamentation of the body surface, length/width ratio of caudal ramus, armature of the fifth swimming leg, and the male sixth swimming leg. In addition, an up-to-date key to the female of all fifteen species of Metacyclops recorded in Asia is provided.
\end{abstract}

Keywords. Cave-dwelling copepod, karst, Sakaerat Environmental Research Station, Satun Province, Southeast Asia.

Athibai S., Wongkamhaeng K. \& Boonyanusith C. 2022. Two new species of Metacyclops Kiefer, 1927 (Copepoda, Cyclopoida) from Thailand and an up-to-date key to the species recorded in Asia. European Journal of Taxonomy 787: 146-181. https://doi.org/10.5852/ejt.2021.787.1621

\section{Introduction}

Metacyclops Kiefer, 1927 is the third largest genus of the subfamily Cyclopinae Kiefer, 1927, represented by 62 species and subspecies (Dussart \& Defaye 2006). Representatives of the genus are known to be 
present in tropical and temperate regions worldwide, particularly in Europe, South America, and Africa (Reid 1991). Its members have been considered polyphyletic, and more recently they have been separated into several different genera after the revision of several species (Fiers 2001; Karanovic 2004a; Karanovic et al. 2011). Based on either fine-detailed re-examination or morphology-based cladistic analysis of the Australian and New Zealand species of Metacyclops, three new genera have been established, including Meridiecyclops Fiers, 2001, Fierscyclops Karanovic, 2004, and Pescecyclops Karanovic, Eberhard \& Murdoch, 2011 (Fiers 2001; Karanovic 2004a; Karanovic et al. 2011).

In the last decade, five new species of Metacyclops have been described, including M. longimaxillis Defaye \& Por, 2010 from a cave in Israel, M. deserticus Mecado-Salas \& Suárez-Morales, 2013 from a desert in Mexico, M. amicitiae Kołaczyński, 2015 from the hyporheic zone of a creek in Vietnam, M. woni Lee \& Chang, 2015 from a temporary pool in Mt. Phnom Domnak Dambouk in Cambodia, and M. thailandicus Boonyanusith, Sanoamuang \& Brancelj, 2018 from a cave in Thailand (Defaye \& Por 2010; Mercado-Salas et al. 2013; Kołaczyński 2015; Lee \& Chang 2015; Boonyanusith et al. 2018b). During 2010-2018, Karanovic et al. (2011) transferred six species of the "trispinosus" group to the genus Pescecyclops and Fiers (2012) removed Allocyclops (Allocyclops) arenicolous (Fryer, 1965) back to the genus Metacyclops.

In this paper, two new representatives of Metacyclops are proposed. One was discovered from a headwater stream in Sakaerat Environmental Research Station (SERS) located at the Sankhampaeng Mountain Range of Nakhon Ratchasima Province, Northeast Thailand. The second was collected from three caves of the Nakhon Sri Thammarat Mountain Range in Satun and Songkhla Provinces, South Thailand.

\section{Material and methods}

A plankton net with $60 \mu \mathrm{m}$ mesh size was used to collect samples in headwater stream in SERS, Nakhon Ratchasima Province, and a hand net with $60 \mu \mathrm{m}$ mesh size was used to collect samples in temporary pools, which are found in the vadose zone of the caves of Satun and Songkhla Provinces (Fig. 1). Samples were subsequently fixed in $4 \%$ formaldehyde solution. In the laboratory, copepods were sorted and stored in $70 \%$ ethanol. Before the morphological examination, adult of both female and male were placed in a mixture of glycerol and 70\% ethanol (ratio $\sim 1: 10 \mathrm{v} / \mathrm{v}$ ) for 30 minutes and later placed in a drop of glycerol between a pair of coverslips on a glass slide, one by one. Habitus was then examined using a Nikon ECLIPSE E200 compound light microscope at a magnification of $1000 \times$. Each specimen was later dissected and mounted on slides by using glycerol as a mounting medium. Subsequently, morphological examination was done using $400 \times$ and $1000 \times$ magnifications. Habitus and dissected body parts were drawn using a drawing tube (Nikon Y-IDT) attached to a compound microscope and the Adobe Illustrator CC 2020 was adopted to prepare the final versions of illustrations. For scanning electron microscopy (SEM), additional material was dehydrated by a series of ethanol concentrations: $70 \%, 80 \%, 90 \% 95 \%$ and $100 \%$, and then by the critical point drying process. Afterwards, specimens were mounted on stubs, coated with gold, and photographs were taken by a scanning electron microscope (FIB-FESEM).

Species descriptions were made following descriptive terminology of Huys \& Boxshall (1991). The following abbreviations are used throughout the text:

$$
\begin{array}{ll}
\text { ae } & =\text { aesthetasc } \\
\text { enp } & =\text { endopod } \\
\text { enp-1 (2) } & =\text { proximal (distal) segment of endopod of swimming legs } \\
\exp & =\text { exopod } \\
\text { exp-1 (2) } & =\text { proximal (distal) segment of exopod of swimming legs } \\
\text { I } & =\text { spine } \\
\text { P1-P6 } & =\text { first to sixth swimming legs }
\end{array}
$$


seta $\mathrm{I}-\mathrm{VII}=$ first to seventh caudal seta

seta I $=$ anterolateral accessory seta

seta II = anterolateral seta

seta III = postereolateral seta

seta IV = outer terminal seta

seta $\mathrm{V}=$ inner terminal seta

seta VI = terminal accessory seta

seta VII $=$ dorsal seta

\section{Repository}

$\mathrm{ZMB}=$ Museum für Naturkunde Berlin (Germany)
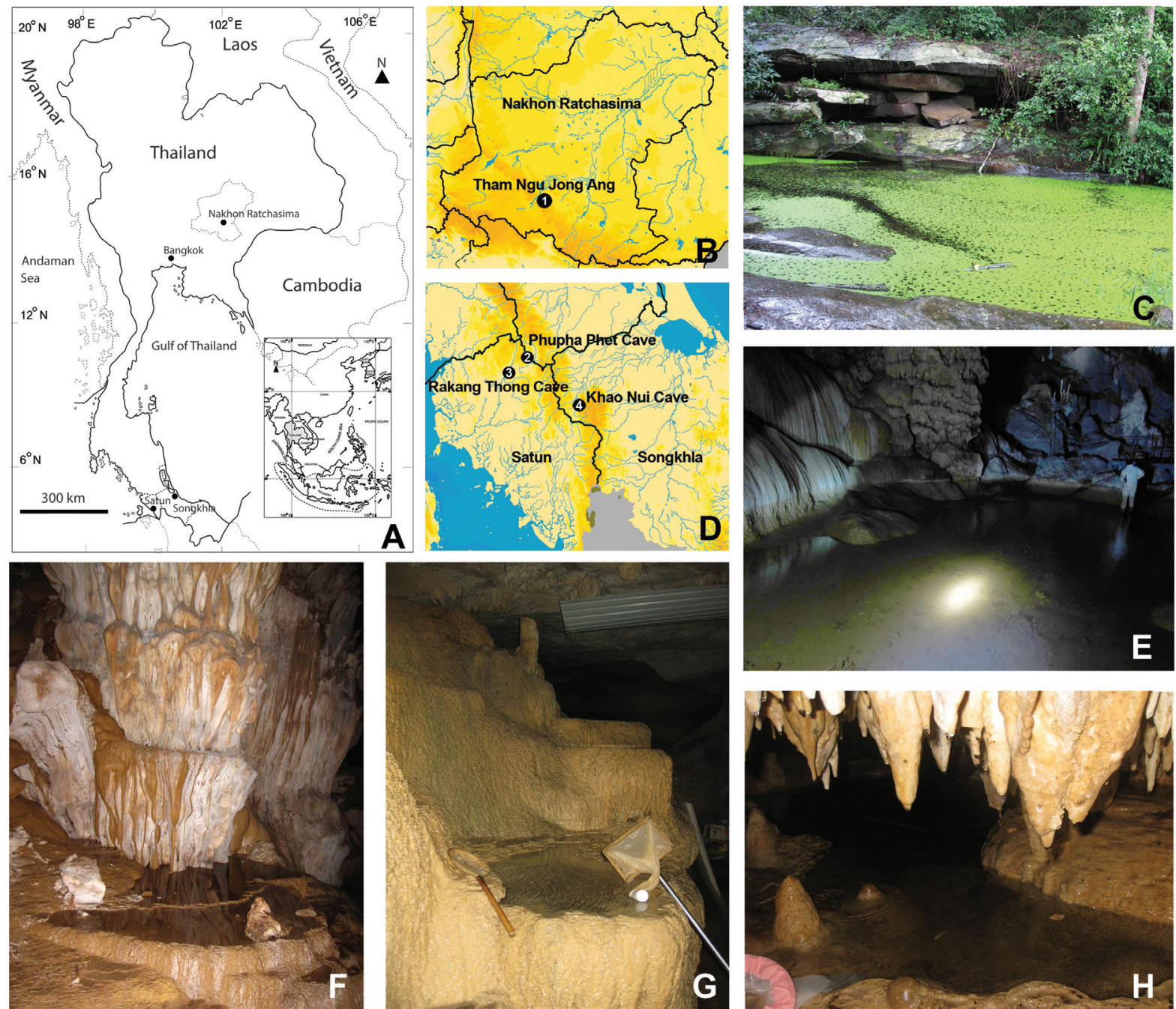

A
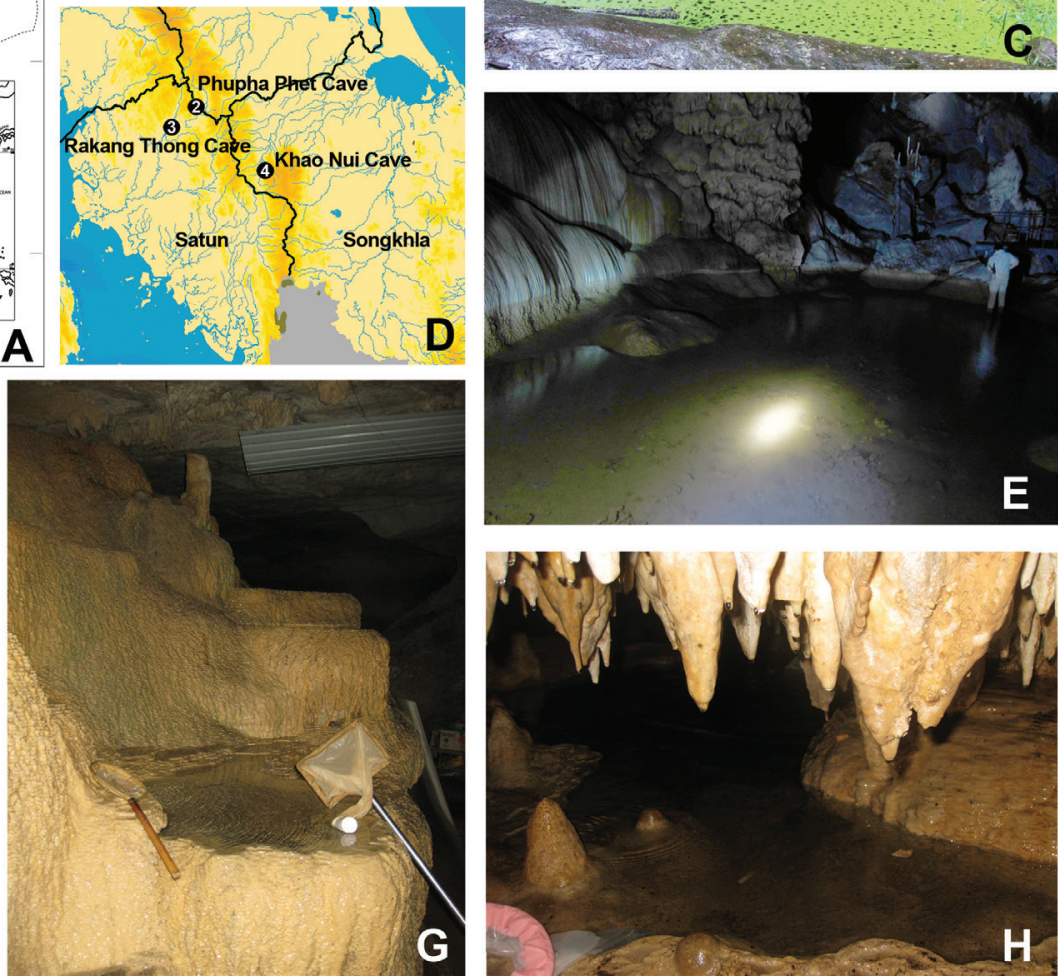

Fig. 1. Geographical location and details of the sampling sites. A. Map of Thailand and a location of Nakhon Ratchasima, Satun and Songkhla Provinces. B-C. Location (indicated by a black circle with no. 1) and sampling point of headwater stream in Nakhon Ratchasima Province. D. Locations of caves in Satun and Songkhla Provinces (indicated by black circles with nos 2, 3, 4). E-F. Sampling points in Phupha Phet Cave. G-H. Sampling points in Rakhang Thong Cave and Khao Nui Cave, respectively. 


\title{
Results
}

\section{Taxonomy}

\author{
Phylum Arthropoda von Siebold, 1848 \\ Subphylum Crustacea Brünnich, 1772 \\ Class Maxillopoda Dahl, 1956 \\ Subclass Copepoda Milne-Edwards, 1840 \\ Superorder Podoplea Giesbrecht, 1882 \\ Order Cyclopoida Burmeister, 1834 \\ Family Cyclopidae Rafinesque, 1815 \\ Subfamily Cyclopinae Kiefer, 1927 \\ Genus Metacyclops Kiefer, 1927 \\ Metacyclops sakaeratensis sp. nov. \\ urn:Isid:zoobank.org:act:84533C2C-57F3-47AB-8EF3-0DF17C9B4C92
}

Figs 2-9; Tables 1-2

\section{Diagnosis}

Female. Body size moderate $(0.73-0.75 \mathrm{~mm} ; \mathrm{n}=3)$, with shallow integumental pits. Posterior margin of second pedigerous somite undulated; those of third and fifth pedigerous somites with serrated hyaline frill. Genital double-somite dorsally with two sensilla and transverse suture, representing the remnant of ancestral articulation of the sixth thoracic somite and the first abdominal somite. Anal operculum developed, reaching insertion of caudal ramus; free margin smooth and straight. Caudal rami ca 2.1-2.3 $\times$ as long as wide, with few spinules at anterior third length on lateral surface and at base of seta II, combined with a row of strong spinules latero-ventrally at base of seta III. Seta VI slightly shorter than seta III. Setal and spine formulae of exp-2 of P1-P4 5.5.5.5 and 3.4.4.3, respectively. P4 exp-2 with single apical spine; spine slightly shorter than segment. Inner spine on free segment of P5 as long as segment; outer seta on P5 ca $4.5 \times$ as long as inner spine.

MALE. Body slenderer and smaller than female $(0.62-0.67 \mathrm{~mm} ; \mathrm{n}=3)$. Caudal rami ca $2.2-2.4 \times$ as long as wide. P6 with two elements; outer (dorsal) seta about twice as long as inner (ventral) spine.

\section{Etymology}

The species name is a noun. The specific epithet was raised after the 'Sakaerat' Subdistrict, where the new species was encountered.

\section{Type material}

\section{Holotype}

THAILAND • $\bigcirc$ (completely dissected and mounted on one slide in glycerol and sealed with nail polish); Nakhon Ratchasima Province, Sakaerat Subdistrict; 14³0'21.60" N, 101 $55^{\prime} 08.40^{\prime \prime}$ E; 14 Sep. 2013; C. Boonyanusith leg.; plankton net; ZMB 34230 slide No. 5120.

\section{Allotype}

THAILAND • $\widehat{\Im}$ (completely dissected and mounted on one slide in glycerol and sealed with nail polish); same collection data as for holotype; ZMB 34230 slide No. 5121.

\section{Paratypes}

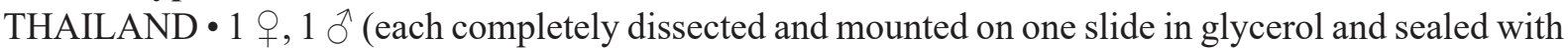
nail polish); same collection data as for holotype; ZMB 34230 slide No. 5122-5123 • 1 q adult (stored in a mixture of glycerol and 70\% ethanol (ratio $\sim 1: 10 \mathrm{v} / \mathrm{v}$ )); same collection data as for holotype; ZMB 34230 . 


\section{Additional material examined}

THAILAND $\bullet 1 \%, 1$ (stored in a mixture of glycerol and 70\% ethanol (ratio $\sim 1: 10 \mathrm{v} / \mathrm{v})$ ); same collection data as for holotype; collection of the third author (CB) $\bullet 2$ 우 (processed for taking photographs by $\mathrm{SEM})$; same collection data as for holotype; collection of the third author (CB).

\section{Type locality}

The new species was collected in a headwater stream in SERS, Sakaerat Subdistrict, Nakhon Ratchasima Province, Northeast Thailand (Fig. 1A-C). The locality is located in a dry evergreen forest and has been known under the name of "Tham Ngu Jong Ang" (King cobra Cave) in Thai language. The name refers to a rock shelter, which is the characteristic of the stream bank in the type locality. The stream reach is about $30 \mathrm{~m}$ long and about 4-5 m wide, streambed with bedrock. During dry season, the water does not encompass the channel entirely. The new species was collected in pool-formed area, where the water flows slowly. The mean water temperature was $25.3^{\circ} \mathrm{C}, \mathrm{pH} 6.98$, conductivity $64.7 \mu \mathrm{S} \mathrm{cm}^{-1}$, and dissolved oxygen $9.1 \mathrm{mg} \mathrm{L}^{-1}$.

\section{Description}

\section{Adult female}

Total body length, measured from tip of rostrum to posterior margin of caudal rami, $0.73-0.75 \mathrm{~mm}$ $($ mean $=0.75 \mathrm{~mm} ; \mathrm{n}=3$; holotype $=0.74 \mathrm{~mm})($ Fig. 2A). Naupliar eye not discernible. Rostrum V-shaped in frontal view, completely fused to cephalothorax, with two sensilla laterally and rounded tip (Fig. 2B). Prosome ca $64 \%$ of body length and ca $1.75 \times$ as long as length of urosome. Cephalothorax anteriorly oval, ca $33 \%$ of body length and ca $1.15 \times$ as long as wide, with greatest width at posterior margin; posterior margin smooth. Posterior margin of second pedigerous somite undulated, third pedigerous somite with serrated hyaline frill on posterior margin, posterior margin of fourth pedigerous somite smooth (Fig. 2A, C). Fifth pedigerous somite with two transversal rows of spinules located between proximal seta and free segment of P5 (Fig. 3B, D), with two sensilla dorsally; posterior margin with serrated hyaline frill (Fig. 2D). Genital somite and first abdominal somite fused, forming genital double-somite. Genital double-somite symmetrical, ca $0.84 \times$ as long as wide, tapering posteriorly; dorsally with two sensilla and transverse suture, representing the remnant of ancestral articulation (Figs 2D, 4B); posterior margin with serrated hyaline frill (Figs 2D, 3A). Seminal receptacle with clear distinction between anterior and posterior lobes; anterior lobe short and wide; posterior lobe globular, narrower than anterior one (Fig. 3A). Second and third abdominal somites narrower than genital double-somite, ca $56 \%$ of double-somite width, with serrated hyaline frill on posterior margin (Fig. 2D). Anal somite with a row of minute spinules latero-ventrally on posterior margin and two sensilla dorsally at base of anal operculum (Fig. 2D). Anal operculum developed, trapezoidal, reaching insertion of caudal ramus; free margin smooth and straight (Fig. 2D). Body with numerous integumental pits; pits shallow, hard to observe and less developed on anal somite (Figs 2C, 4B, E).

Caudal Rami (Figs 2D, 3C, 4C). Relatively short, ca $2.25 \times$ as long as wide, with six setae; all setae pinnate. Seta I absent. Seta II inserted at $1 / 3$ of caudal ramus length. Seta III spiniform, inserted at posterior outer corner of ramus. Seta IV and seta V with breaking planes. Seta V, the longest, ca $0.34 \times$ as long as body length. Seta VI slender, slightly shorter than seta III. Seta VII inserted dorso-medially at $1 / 5$ of ramus length. Length ratio of caudal setae to ramus length, from seta II to seta VII: $0.37: 0.91: 4.23: 5.57: 0.86$ : 1.21. Lateral surface ornamented with few minute spinules located at anterior $1 / 3$ of ramus length, few minute spinules at base of seta II, and a row of strong spinules at base of seta III.

ANTENNULE (Fig. 5A). Eleven-segmented, reaching ca $2 / 3$ of cephalothorax; armature formula: 1-[8], 2-[4], 3-[6], 4-[2], 5-[1+I], 6-[2], 7-[3], 8-[2+ae], 9-[2], 10-[2+ae], 11-[8]. Fifth segment with short spine on posterior outer corner. Aesthetasc on eighth and tenth segments slender, inserted near outer seta, as long as outer seta. Eleventh segment with acrothek sub-apically. 


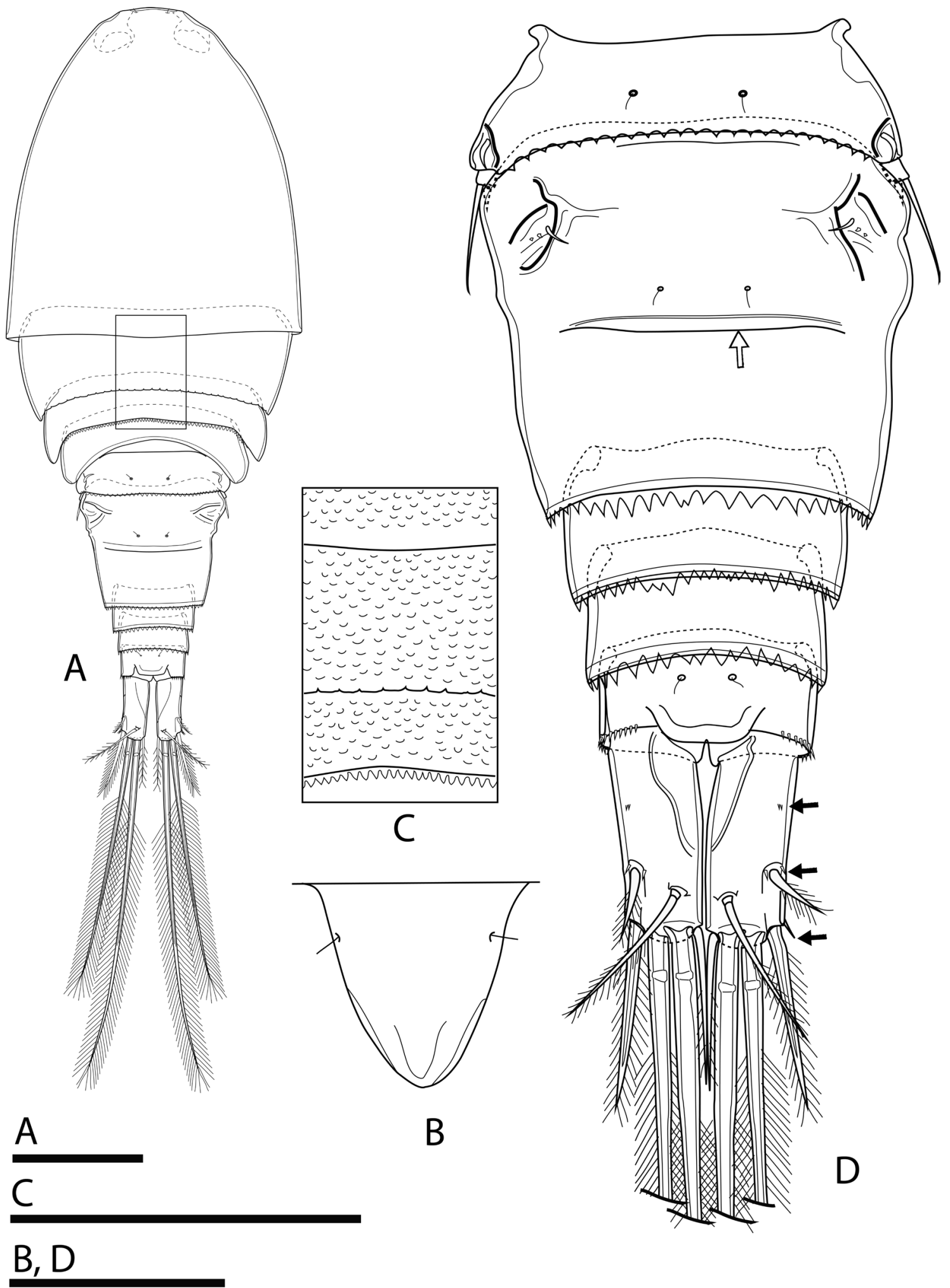

Fig. 2. Metacyclops sakaeratensis sp. nov., paratype, $q$ (A, C; ZMB 34230) and holotype, $q$ (B, D; ZMB 34230 slide No. 5120). A. Habitus, dorsal view. B. Rostrum, frontal view. C. Integumental pits and posterior margins of cephalothorax and two subsequent pedigerous somites, dorsal view. D. Urosome, dorsal view (black and open arrows indicate spinules and transverse suture, respectively). Scale bars: A, $\mathrm{C}=100 \mu \mathrm{m} ; \mathrm{B}, \mathrm{D}=50 \mu \mathrm{m}$. 


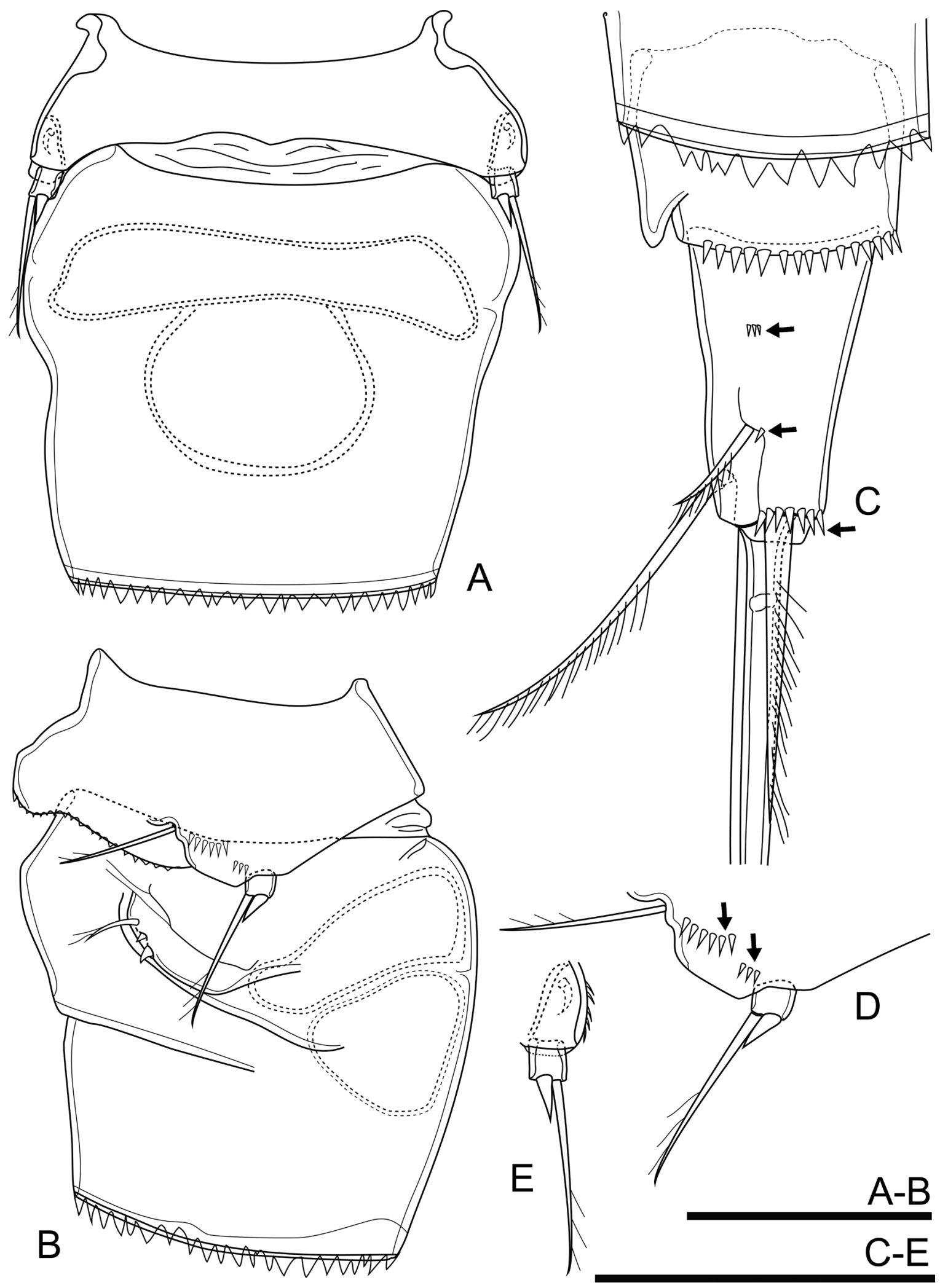

Fig. 3. Metacyclops sakaeratensis sp. nov., holotype, $q$ (ZMB 34230 slide No. 5120). A-B. Fifth pedigerous somite and genital double-somite, ventral and lateral views, respectively. C. Caudal ramus, lateral view (arrows indicate spinules). D-E. P5, lateral and ventral views, respectively (arrows in D indicate rows of spinules on the lateral surface of the fifth pedigerous somite). Scale bars $=50 \mu \mathrm{m}$. 

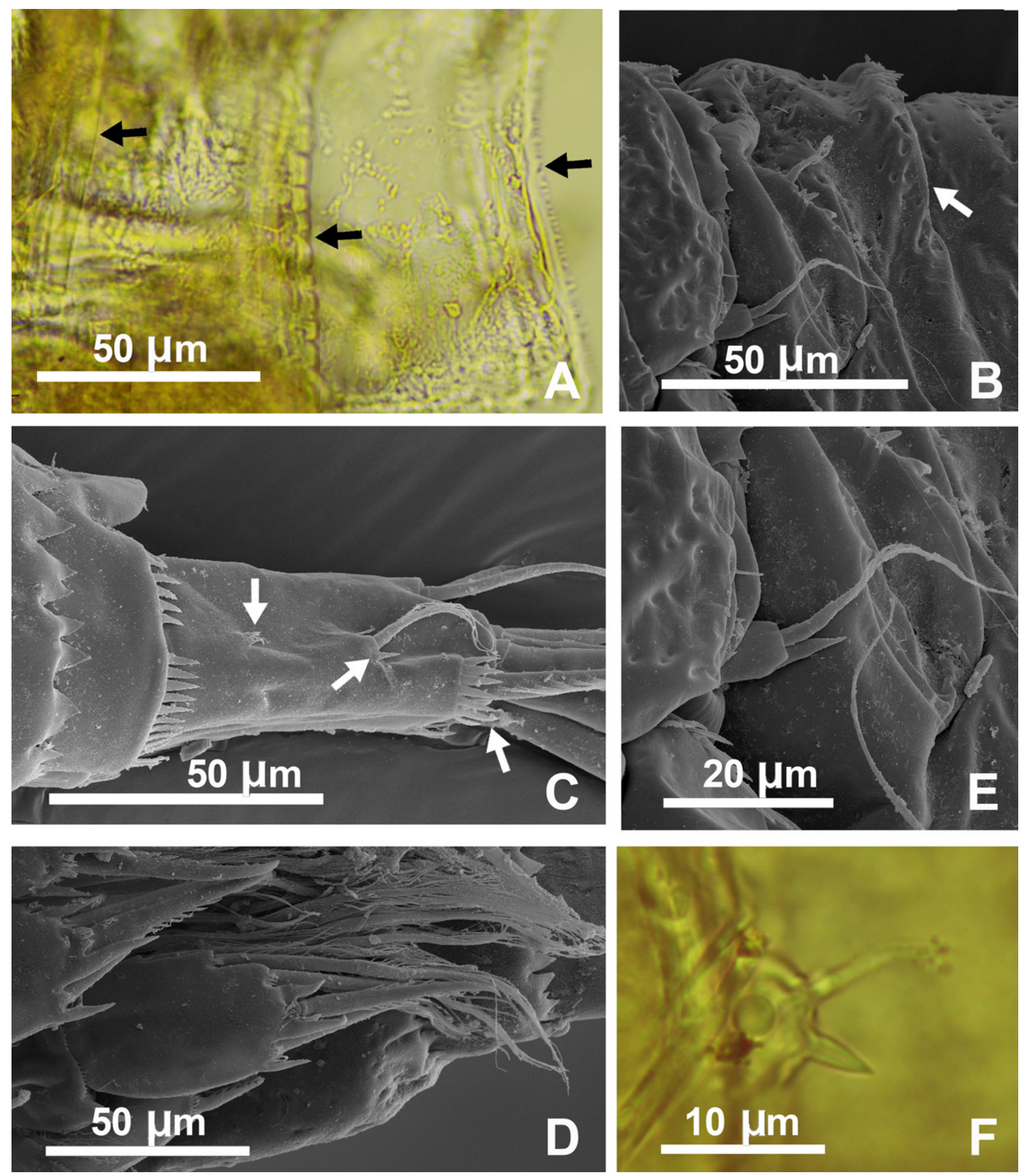

Fig. 4. Metacyclops sakaeratensis sp. nov., digital photographs of allotype, §̂ (A, F; ZMB 34230 slide No. 5121) and SEM photographs of additional material, $O+9$ (B-E; collection of the third author CB). A. Posterior margins of cephalothorax and two subsequent pedigerous somites, dorso-lateral view (arrows indicate posterior margin of the second, third and fourth pedigerous somites). B. Anterior part of genital double-somite, lateral view (arrow indicates posterior margin of the transverse suture). C. Caudal ramus,

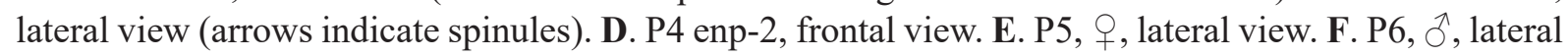
view. 


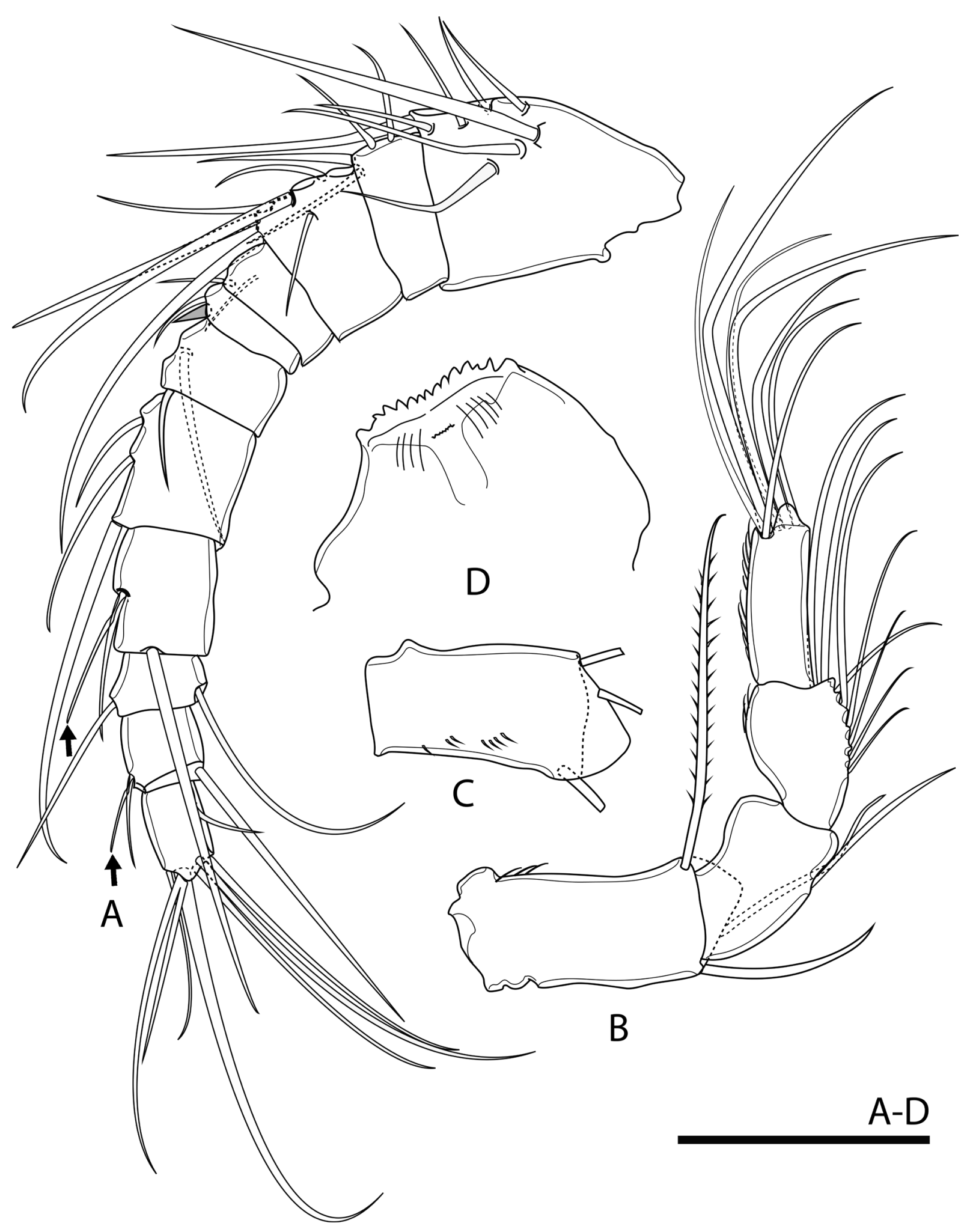

Fig. 5. Metacyclops sakaeratensis sp. nov., holotype, $q$ (A-B; ZMB 34230 slide No. 5120) and paratype, q (C-D; ZMB 34230 slide No. 5122). A. Antennule (arrows indicate aesthetascs). B. Antenna, frontal surface. C. Coxobasis of antenna, caudal surface. D. Labrum, inner side. Scale bar $=50 \mu \mathrm{m}$. 


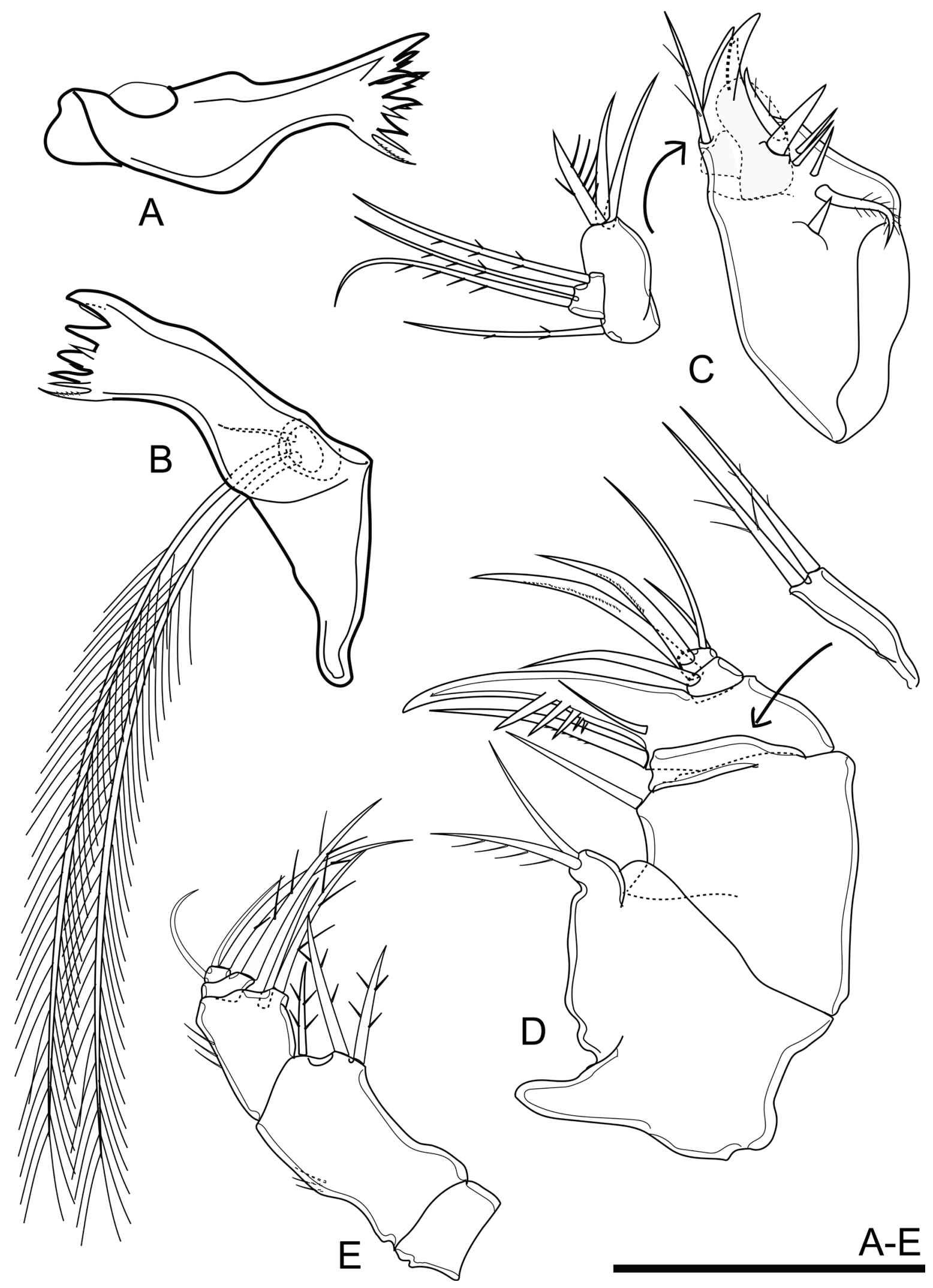

Fig. 6. Metacyclops sakaeratensis sp. nov., holotype, $q$ (ZMB 34230 slide No. 5120). A-B. Right and left mandibles, respectively (the mandibular palp of the right mandible was lost during dissection). C. Maxillule, caudal view. D. Maxilla, caudal view. E. Maxilliped, frontal view. Scale bar $=50 \mu \mathrm{m}$. 
Antenna (Fig. 5B-C). Four-segmented, comprising coxobasis and three-segmented enp; setal formula 3.1.9.7. Coxobasis robust, with three transversal rows of spinules on caudal surface; two smooth setae on inner distal corner; seta representing exp spinulose, inserted on outer distal corner and reaching tip of enp-3. Enp-1 ca $1.5 \times$ as long as wide, with smooth seta on medial margin. Enp- 2 ca $1.5 \times$ as long as wide, with longitudinal row of minute spinules on outer margin and nine setae; seven setae inserted along medial margin and two setae inserted apically. Enp-3 ca $2.0 \times$ as long as wide, with two longitudinal rows of minute spinules along outer margin and seven smooth setae apically; outermost seta shortest.

LABRUM (Fig. 5D). Trapezoidal in frontal view, with two rows of hairs; cutting edge with 12 teeth medially between two obtuse lateral teeth.

MANDIBLE (Fig. 6A-B). Gnathobase with strongly chitinized teeth on cutting edge and spinulose seta dorsally; seta completely fused to segment. Palp reduced, one-segmented, with one short, slender seta and two long, bipinnate setae; two long setae subequal in length, ca $10 \times$ as long as shorter one.

MAXILlule (Fig. 6C). Three-segmented, composed of robust praecoxa and two-segmented maxillulary palp, representing coxobasis and enp. Arthrite of praecoxa with three strong claw-like extensions apically and one spinulose seta sub-apically. Praecoxa with seven elements along medial margin; proximalmost seta minute, sub-proximal seta robust and spinulose, three middle setae slender and smooth, sub-distal seta robust and smooth, distalmost seta robust and spinulose. Basal segment of palp with three elements apically; outer apical seta robust and armed with long spinules on outer margin; inner apical and subapical ones smooth. Exp reduced, represented by spinulose seta near lateral segment of palp. Enp represented by lateral segment of palp, with two setae apically and one seta sub-apically; all setae spinulose, subequal in length.

MaxiLLa (Fig. 6D). Five-segmented. Praecoxa and coxa partly fused frontally. Praecoxal endite prominent, inserted medially, with one smooth and one spinulose seta apically. Coxa with two endites; proximal endite with one smooth seta apically; distal endite rectangular, movable, with two spinulose setae apically; spinules on proximal seta on distal endite relatively long, those of distal one minute. Basis with claw-like endite and two setae at base of claw; longest seta strong, inserted ventrally to claw; shorter one slender, inserted on caudal surface above the longest seta; concave margin of claw with oblique row of spinules, spinules fused to basis and increased in size from frontal spinule to caudal one. Enp two-segmented; enp-1 with two robust setae; enp-2 with strong seta apically and two smooth, slender setae sub-apically.

MAXILliPED (Fig. 6E). Four-segmented, composed of syncoxa, basis and two-segmented enp. Syncoxa with two endites and ornamented with a row of spinules on outer margin; proximal endite with two subequal spinulose setae apically; distal endite with one spinulose seta. Basis with one seta on caudal surface; basal endite with one spinulose seta apically. Enp-1 with strong spinulose seta. Enp-2 with three setae; apical seta strong, two other ones slender and smooth.

P1-P4 (Fig. 7). Two-segmented enp and exp. Intercoxal sclerite with minute spinules on distal prominences. Coxa with one seta on distal inner corner. Basis with one seta laterally and hairy medially. Setal and spine formulae of exp-2 of P1-P4: 5.5.5.5 and 3.4.4.3, respectively. Armature of swimming leg as in Table 1.

P1 (Fig. 7A). Frontal and caudal surfaces of intercoxal sclerite bare, with 2-3 minute spinules on distal prominences. Lateral seta on basis ca $4 \times$ as long as those of P2-P4; medial seta pinnate, reaching mid of enp-2. Exp-1 with outer spine and inner seta. Exp-2 as long as wide, with three spines and five setae; apical spine ca $0.7 \times$ as long as segment. Enp- 1 with inner seta. Enp- 2 ca $1.5 \times$ as long as wide, with outer seta inserted between claw-like expansion, apically with robust spine and seta, inner margin with three setae; outer seta ca $1.2 \times$ as long as length of apical spine; apical spine strong, slightly curved, as long as segment. 
Table 1. Armature formula of P1-P4 in Metacyclops sakaeratensis sp. nov. and M. brancelji sp. nov. Roman numerals represent number of spines and Arabic numerals represent number of setae.

\begin{tabular}{lcccccc}
\hline \multirow{2}{*}{ Swimming leg } & \multirow{2}{*}{ Coxa } & \multirow{2}{*}{ Basis } & \multicolumn{2}{c}{ Exopod } & \multicolumn{2}{c}{ Endopod } \\
\cline { 4 - 7 } & & & $\mathbf{1}$ & $\mathbf{2}$ & $\mathbf{1}$ & $\mathbf{2}$ \\
\hline P1 & $0-1$ & $1-1$ & I-1 & II-I $+1-4$ & $0-1$ & $1-\mathrm{I}+1-3$ \\
P2 & $0-1$ & $1-0$ & I-1 & III-I $+1-4$ & $0-1$ & $1-\mathrm{I}+1-4$ \\
P3 & $0-1$ & $1-0$ & I-1 & III-I $+1-4$ & $0-1$ & $1-\mathrm{I}+1-4$ \\
P4 & $0-1$ & $1-0$ & I- 0 & II-I $+1-4$ & $0-1$ & $1-\mathrm{I}-3$ \\
\hline
\end{tabular}

P2 (Fig. 7B). Intercoxal sclerite as in P1, yet distal prominences with 3-4 minute spinules. Basis with two hook-like expansions: outer expansion located between insertions of exp and enp; inner one smaller, located at the same place where the medial seta of basis of P1 inserted. Lateral seta on basis ca $0.25 \times$ as long as that of P1. Exp-1 with outer spine and inner seta. Exp- 2 ca $1.3 \times$ as long as wide, with four spines and five setae; apical spine slightly shorter than segment. Enp-1 with inner seta. Enp-2 ca $1.5 \times$ as long as wide, with outer seta inserted between claw-like expansion, apically with robust spine and seta, inner margin with four setae; outer seta inserted between claw-like extensions, ca $1.3 \times$ as long as length of apical spine; apical spine strong and straight, as long as segment.

P3 (Fig. 7C-D). Frontal surface of intercoxal sclerite bare; caudal surface with transversal row of minute spinules and distal prominences with 3-4 minute spinules. Basis, exp, and enp similar to those of P2.

P4 (Figs 4D, 7E). Intercoxal sclerite similar to that of P3. Coxa with rows of spinules on caudal surface. Basis similar to those of P2 and P3. Exp-1 with outer spine. Exp-2 ca $2.0 \times$ as long as wide, with three spines and five setae; spines smaller than those of P1-P3, apical spine ca $0.5 \times$ as long as segment. Enp1 with inner seta. Enp-2 ca $2.0 \times$ as long as wide, with outer seta inserted between claw-like expansion, apically with robust spine and seta, inner margin with four setae; outer seta ca $1.3 \times$ as long as length of apical spine; apical spine ca $0.8 \times$ as long as segment.

P5 (Figs 3A-B, D-E, 4E). One-segmented, inserted on postero-lateral corner of fifth pedigerous somite. Proximal segment completely fused to somite, represented by lateral seta. Distal segment free, subquadrate, ca $1.1 \times$ as long as wide, apically with one slender outer seta and one inner spine; inner spine as long as segment and outer seta ca $4.5 \times$ as long as inner spine.

P6 (Figs 3B, 4B). Small, forming simple cuticular plate inserted latero-dorsally on genital double-somite, and armed with one seta dorsally and two minute spiniform setae ventrally.

\section{Adult male}

Total body length, excluding caudal seta, $0.62-0.67 \mathrm{~mm}($ mean $=0.65 \mathrm{~mm} ; \mathrm{n}=3$; allotype $=0.65 \mathrm{~mm})$. Habitus smaller and slenderer than in female (Fig. 8A). Naupliar eye and rostrum as in female. Prosome ca $62 \%$ of body length and ca $1.62 \times$ as long as length of urosome. Cephalothorax anteriorly oval, representing ca $33 \%$ of body length and ca $1.16 \times$ as long as wide. Posterior margins of cephalothorax and two subsequent pedigerous somites (Fig. 4A) similar to those of female; that of fourth pedigerous somite smooth. Fifth pedigerous somite as that of female. Genital somite swollen on mediolateral margin (Fig. 8A-B), ca $25 \%$ length of urosome and ca $0.62 \times$ as long as wide, with hyaline frill latero-dorsally. First to third abdominal somites narrower than genital somite, representing ca $60 \%$ of genital somite width, with serrated hyaline frill on posterior margin. Anal somite and operculum similar to those of female. 


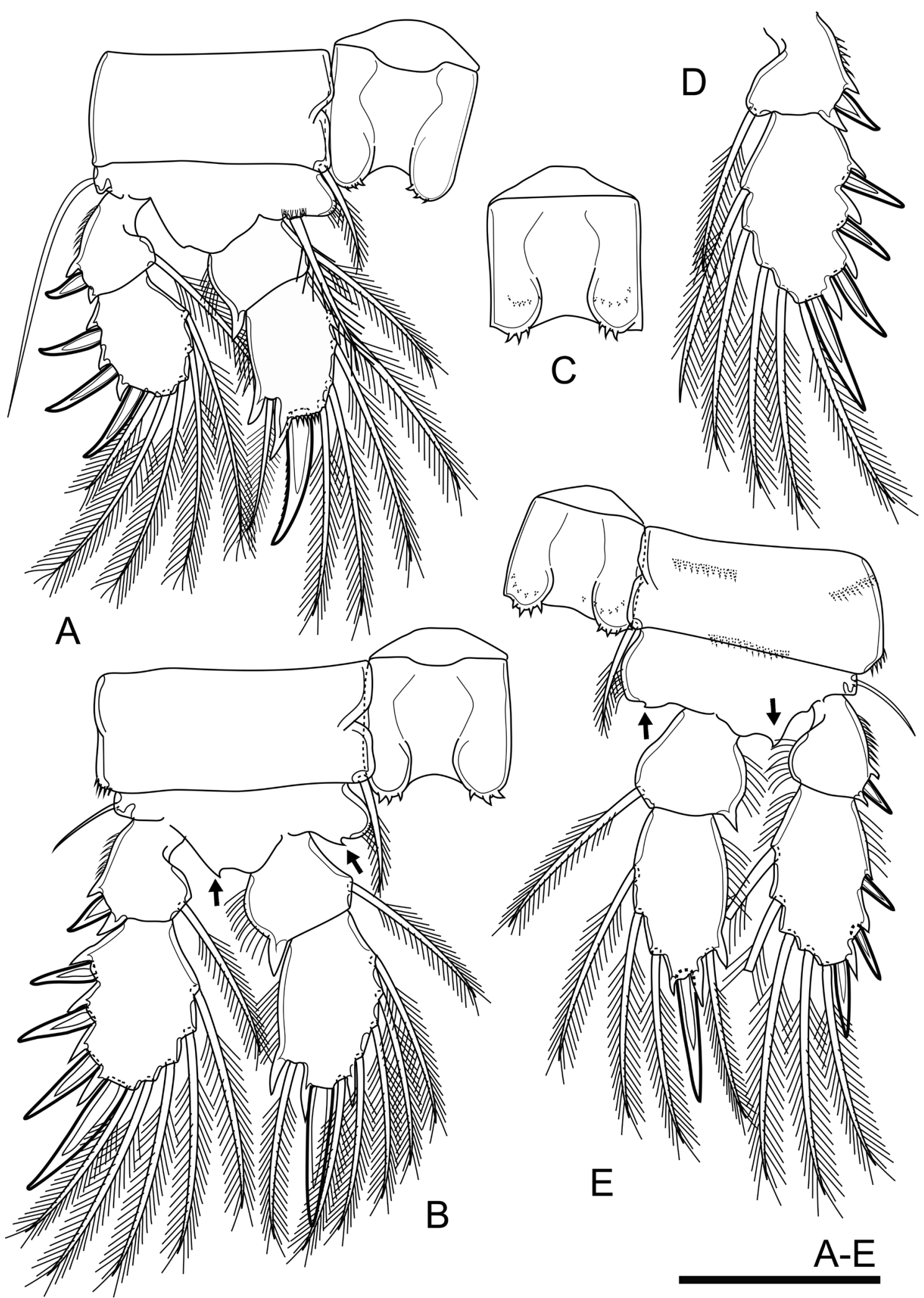

Fig. 7. Metacyclops sakaeratensis sp. nov., holotype, $q$ (ZMB 34230 slide No. 5120). A. P1, frontal view. B. P2, frontal view. C. Frontal view of intercoxal sclerite of P3. D. P3 exp-1. E. P4, frontal view. Arrows indicate hook-like expansion. In $\mathrm{C}$ and $\mathrm{E}$, the spinule row is on the caudal surface of intercoxal sclerite and coxa. Scale bar $=50 \mu \mathrm{m}$. 

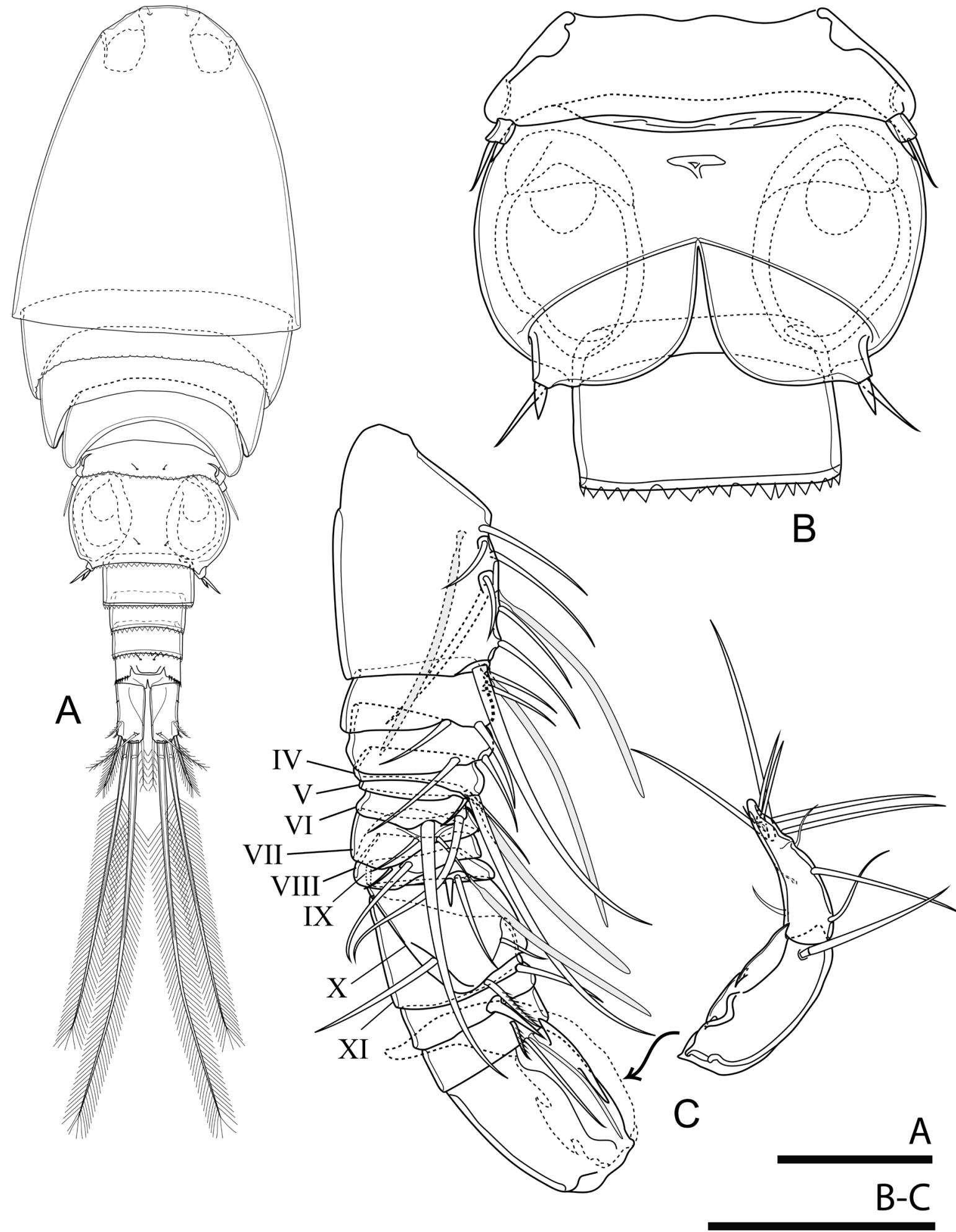

Fig. 8. Metacyclops sakaeratensis sp. nov., paratype, $\widehat{\jmath}$ (A; ZMB 34230 slide No. 5123) and allotype, $\widehat{\partial}$ (B-C; ZMB 34230 slide No. 5121). A. Habitus, dorsal view. B. Genital and first abdominal somites, ventral view. C. Antennule (Roman numerals indicate segment of antennule). Scale bars: $A=100 \mu \mathrm{m}$; $\mathrm{B}-\mathrm{C}=50 \mu \mathrm{m}$. 
Caudal Rami. Similar to that of female, ca $2.3 \times$ as long as wide. Armament and ornamentation similar to those of female. Length ratio of caudal setae to ramus length, from seta II to seta VII: 0.42 : 0.88: 4.47: 5.83: 0.82: 1.27 .

ANTENNULE (Fig. 8C). 16-segmented, geniculate. Armature formula as follows: 1-[8+3ae], 2-[4], 3-[2], 4-[2+ae], 5-[1], 6-[2], 7-[2], 8-[2], 9-[1+ae+I], 10-[2], 11-[2], 12-[I], 13-[2+ae], 14-[0], 15-[1], 16-[12]. Eleventh and thirteenth segments with pinnate seta each.

Antenna, mandible, MaXillule, maXilla, AND maXiLliped. Similar to those of female.

P1. Frontal and caudal surfaces of intercoxal sclerite bare and distal prominences with 2-3 minute spinules (Fig. 9A). Coxa, basis, enp and exp similar to those of female.

P2. Intercoxal sclerite as in P1, yet distal prominences with 3-5 minute spinules (Fig. 9B). Coxa, basis, enp and exp similar to those of female.

P3. Frontal surface of intercoxal sclerite bare, caudal one with transversal row of minute spinules. distal prominences with 3-5 minute spinules (Fig. 9C). Coxa, basis, enp and exp similar to those of female.

P4. Frontal surface of intercoxal sclerite bare, caudal one with transversal row of minute spinules and distal prominences with 3-5 minute spinules (Fig. 9D). Coxa, basis, enp and exp similar to that of female; apical spine on enp- 2 ca $0.8 \times$ as long as segment.

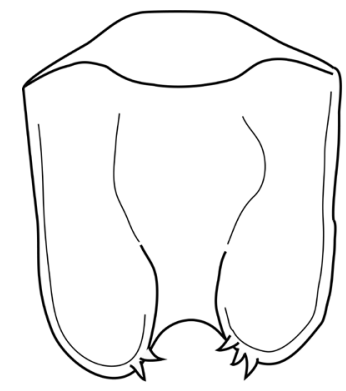

A

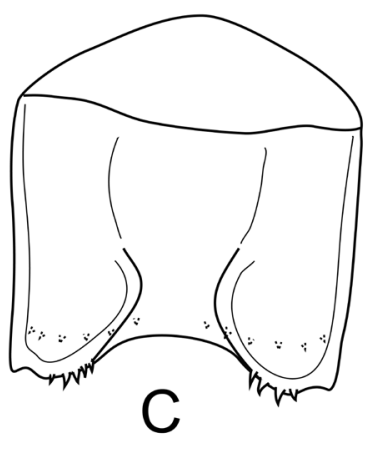

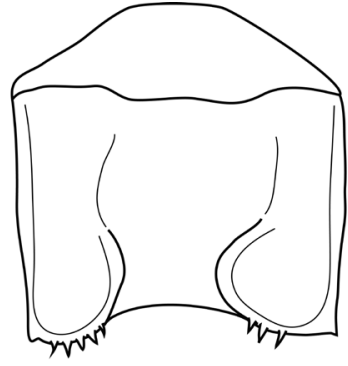

B

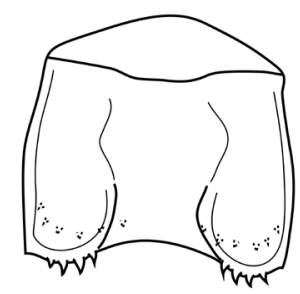

D
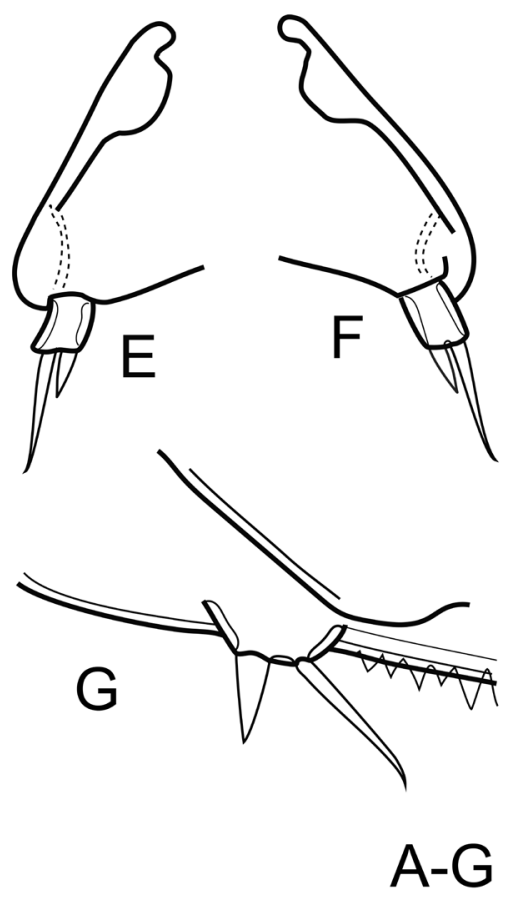

Fig. 9. Metacyclops sakaeratensis sp. nov., paratype, $\widehat{\partial}$ (A-D; ZMB 34230 slide No. 5123) and allotype, ô (E-G; ZMB 34230 slide No. 5121). A-D. Intercoxal sclerites of P1, P2, P3 and P4, respectively, frontal view. E-F. Right and left P5, respectively, ventral view. G. P6, lateral view. In C-D, the spinule row is on the caudal surface of intercoxal sclerite. Scale bar $=50 \mu \mathrm{m}$. 
P5 (Fig. 9E-F). Similar to that of female, yet outer seta on free segment short, ca $2.3 \times$ as long as inner spine.

P6 (Fig. 9G). Reduced to cuticular plate with two elements, inner (ventral) one spine and outer (dorsal) one seta; inner spine ca $0.5 \times$ as long as outer seta.

\section{Variability}

The body length of the female specimens varies in a range of $0.73-0.75 \mathrm{~mm}(\mathrm{n}=3)$ and that of the male specimens is $0.62-0.67 \mathrm{~mm}(\mathrm{n}=3)$. The variations in the length/width ratio of caudal ramus in the female, along with the length of spine on the female P5 and the male P6 are shown in Table 2.

\section{Distribution}

Metacyclops sakaeratensis sp. nov. has been known only from the type-locality.

Metacyclops brancelji sp. nov.

urn:1sid:zoobank.org:act:C420CB65-D63C-4E04-A734-3F5B62D67043

Figs 10-15; Tables 1-2

\section{Diagnosis}

Female. Body size moderate $(0.89-0.96 \mathrm{~mm} ; \mathrm{n}=6)$, without integumental pits. Posterior margin of second pedigerous somite undulated, those of third and fifth pedigerous somite with serrated hyaline frill. Genital double-somite dorsally with two sensilla and transverse suture, representing the remnant of ancestral articulation of the sixth thoracic somite and the first abdominal somite. Anal operculum developed, reaching insertion of caudal ramus; free margin smooth and concave. Caudal rami ca 2.6-2.9 $\times$ as long as wide, ornamented with 3-4 spinules at anterior third length on lateral surface and few spinules at base of seta II, combined with a row of strong spinules latero-ventrally at base of seta III. Seta VI slightly shorter than seta III. Setal and spine formulae of exp-2 of P1-P4 5.5.5.5 and 3.4.4.3, respectively. P4 exp-2 with single apical spine; spine slightly shorter than segment. Inner spine of free segment of P5 longer than segment, ca $1.5 \times$ as long as segment; outer seta on P5 ca $2.5 \times$ as long as inner spine.

MALE. Body length $0.71-0.76 \mathrm{~mm}(\mathrm{n}=3)$. Caudal rami ca $2.5-2.8 \times$ as long as wide. P6 with two elements; inner (ventral) spine robust, slightly shorter than outer seta.

\section{Etymology}

The name is a masculine noun in genitive singular, raised after Professor Dr Anton Brancelj (National Institute of Biology, Ljubljana, Slovenia) in honor of his great contribution to the diversity of subterranean Copepoda in Thailand.

\section{Type material}

\section{Holotype}

THAILAND - $q$ (completely dissected and mounted on a slide in glycerol and sealed with nail polish); Satun Province, Phupha Phet Cave; 707'28.94" N, 9959'52.14" E; 92 m a.s.1.; 17 Dec. 2014; C. Boonyanusith leg.; temporary pool; hand net; ZMB 34231 slide No. 5124.

\section{Allotype}

THAILAND - $\widehat{O}$ (completely dissected and mounted on a slide in glycerol and sealed with nail polish); same collection data as for holotype; ZMB 34231 slide No. 5125. 

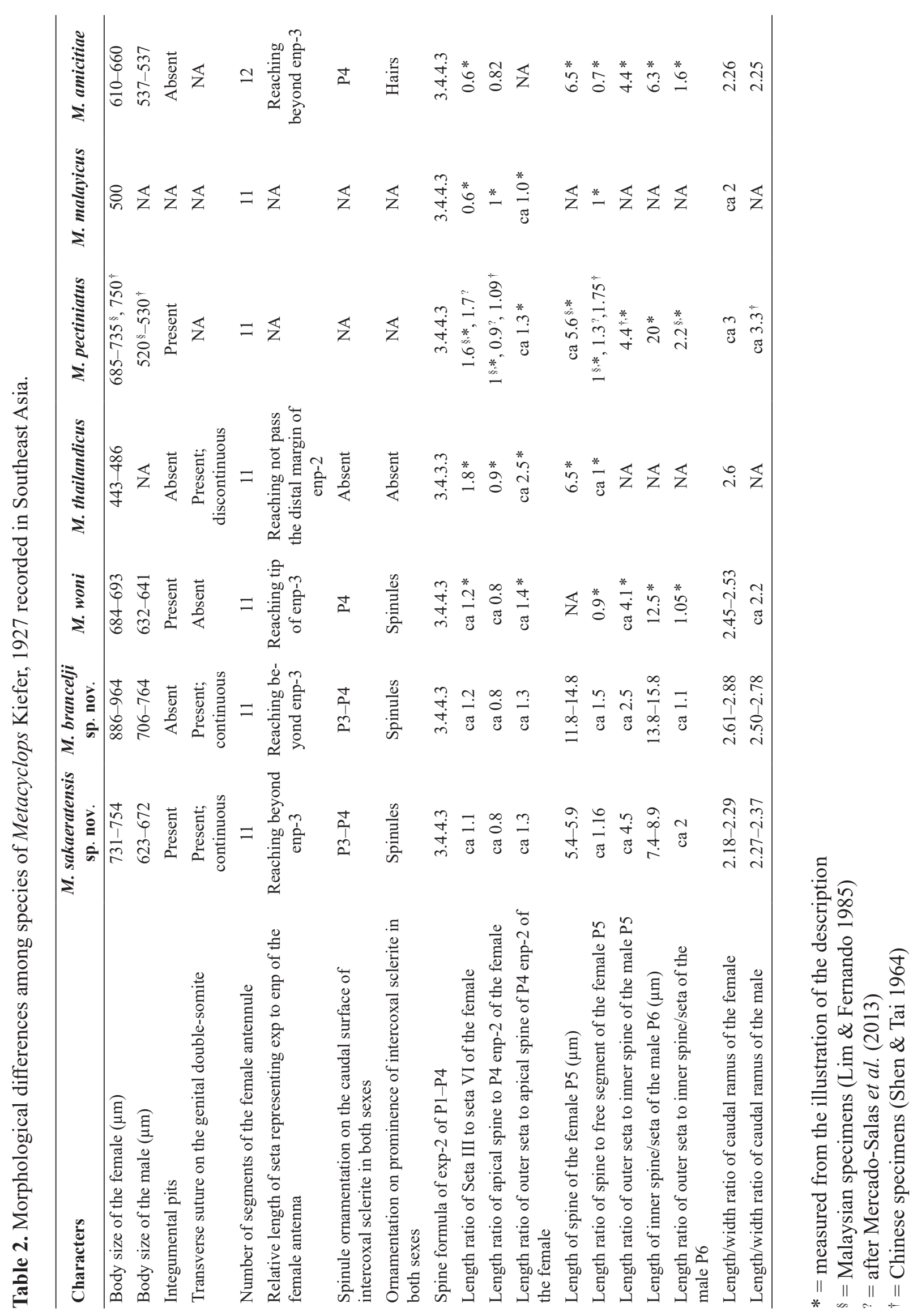


\section{Paratypes}

THAILAND $\bullet 1$ ㅇ, 1 (each completely dissected and mounted on a slide in glycerol and sealed with nail polish); same collection data as for holotype; ZMB 34231 slide No. 5126-5127 • 1 ㅇ (stored in a mixture of glycerol and 70\% ethanol (ratio 1:10 v/v)); same collection data as for holotype; ZMB 34231a.

\section{Additional material examined}

THAILAND - Satun Province $\bullet 1$ q, 1 đ (each completely dissected and mounted on one slide in glycerol and sealed with nail polish); Rakhang Thong Cave; $7^{\circ} 05^{\prime} 42.18^{\prime \prime} \mathrm{N}, 99^{\circ} 55^{\prime} 05.64^{\prime \prime} \mathrm{E} ; 55 \mathrm{~m}$ a.s.1.; 31 Jul. 2015; C. Boonyanusith leg; rimstone; hand net; ZMB 34231 slide No. 5128-5129 • 1 ๙ (specimen stored in a mixture of glycerol and 70\% ethanol (ratio $\sim 1: 10 \mathrm{v} / \mathrm{v}$ )); same collection data as for preceding; ZMB 34231b・ 2 우, 1 \ (processed for taking photographs by SEM); same collection data as for the preceding; collection of the third author (CB). - Songkhla Province 1 \& (completely dissected and mounted on a slide in glycerol and sealed with nail polish); Khao Nui Cave; 6 $6^{\circ} 59^{\prime} 32.16^{\prime \prime} \mathrm{N}$, $100^{\circ} 08^{\prime} 28.35^{\prime \prime}$ E; $78 \mathrm{~m}$ a.s.1.; 15 Dec. 2014; C. Boonyanusith leg; ; pool filled by dripping water; hand net; ZMB 34231 slide No. 5130 • 1 \& (specimen stored in a mixture of glycerol and 70\% ethanol (ratio $\sim 1: 10 \mathrm{v} / \mathrm{v})$ ); same collection data as for preceding; ZMB 34231c

\section{Type locality}

The new species was collected from a pool in Phupha Phet Cave, Manang District, Satun Province, southern Thailand (Fig. 1A, D). The cave is located in a limestone hill of the Nakhon Sri Thammarat Mountain range. Beyond the entrance there is a very large cave tunnel, separated to several rooms and decorated well with stalactites, stalagmites, flowstones and rimstones, with a wooden bridge throughout the cave and installed lights. The collecting point is about 100 meters from the entrance, being a large temporary pool in the room, named "Dok Boa Khwam" (Upside-down lotus flower). Water comes primarily from the epikarst zone of the cave, and the depth varies according to season, ranging from 5 $\mathrm{cm}$ in dry season to $40 \mathrm{~cm}$ in rainy season. In collecting date, the water was about $40 \mathrm{~cm}$ deep, covering an area of about $30 \mathrm{~m}^{2}$, transparent and colorless.

\section{Description}

\section{Adult female}

Total body length, measured from tip of rostrum to posterior margin of caudal rami, $0.89-0.96 \mathrm{~mm}$ $($ mean $=0.94 \mathrm{~mm} ; \mathrm{n}=6$; holotype $=0.89 \mathrm{~mm})($ Fig. 10A $)$. Body without integumental pits $($ Fig. 11A-B). Naupliar eye not discernible. Rostrum V-shaped in frontal view, with rounded tip, completely fused to cephalothorax, with two sensilla laterally. Prosome ca $65 \%$ of body length and ca $1.87 \times$ as long as length of urosome. Cephalothorax anteriorly oval, ca $32 \%$ of body length and ca $1.08 \times$ as long as wide, with greatest width at posterior end; posterior margin smooth. Posterior margin of second pedigerous somite undulated; third pedigerous somite with serrated hyaline frill on posterior margin; posterior margin of fourth pedigerous somite smooth (Figs 10A, 11A). Fifth pedigerous somite with two transversal rows of spinules located between proximal seta and free segment of P5, with two sensilla dorsally; posterior margin with serrated hyaline frill. Genital double-somite symmetrical, ca $0.82 \times$ as long as wide, tapering posteriorly, dorsally with two sensilla and transverse suture, representing the remnant of ancestral articulation; posterior margin with serrated hyaline frill (Figs 10A-B, 11B). Seminal receptacle with clear distinction between anterior and posterior lobes; anterior lobe short and wide; posterior lobe globular, narrower than anterior one. Second and third abdominal somites narrower than genital doublesomite, ca $56 \%$ of double-somite width, with serrated hyaline frill on posterior margin (Figs 10A, 11B). Anal somite with row of minute spinules latero-ventrally on posterior margin and two sensilla dorsally at base of anal operculum (Fig. 10C). Anal operculum developed, trapezoidal, reaching insertion of caudal ramus; free margin smooth and concave (Fig. 10C). 
Caudal RAmi (Figs 10C-D, 11C). Relative short, ca $2.7 \times$ as long as wide, with six setae; all setae pinnate. Seta I absent. Seta II inserted at $1 / 3$ of caudal ramus length. Seta III spiniform, inserted at posterior outer corner of ramus. Seta IV and seta V with breaking planes. Seta V, the longest, ca $0.33 \times$ as long as body length. Seta VI slender, slightly shorter than seta III. Seta VII inserted dorso-medially at $1 / 5$ of ramus length. Length ratio of caudal setae to ramus length, from seta II to seta VII: 0.27: 0.84: 3.82: 4.98: 0.70: 0.82. Lateral surface ornamented with 4-5 minute spinules located at anterior $1 / 3$ of ramus length, with few minute spinules at base of seta II and a row of strong spinules latero-ventrally at base of seta III.

ANTENNULE (Fig. 12A). Eleven-segmented, reaching ca $2 / 3$ of cephalothorax; armature formula: 1-[8], 2-[4], 3-[6], 4-[2], 5-[1+I], 6-[2], 7-[3], 8-[2+ae], 9-[2], 10-[2+ae], 11-[8]. Fifth segment with short spine on posterior outer corner. Aesthetasc on eighth and tenth segments slender, inserted near outer seta, as long as seta. Eleventh segment with acrothek sub-apically.

ANTENNA (Fig. 12B). Four-segmented, comprising coxobasis and three-segmented enp; setal formula 3.1.9.7. Coxobasis robust, with three transversal rows of spinules on caudal surface and two smooth setae on inner distal corner; seta representing exp spinulose, inserted on outer distal corner and reaching tip of enp-3. Enp- 1 ca $1.5 \times$ as long as wide, with smooth seta on medial margin. Enp- 2 ca $1.5 \times$ as long as wide, with longitudinal row of minute spinules on outer margin and nine setae; seven setae inserted along medial margin and two setae inserted apically. Enp-3 ca $2.0 \times$ as long as wide, with two longitudinal rows of minute spinules along outer margin and seven smooth setae apically; outermost seta shortest.

MANDible (Fig. 12C). Gnathobase with strongly chitinized teeth on cutting edge and spinulose seta dorsally; seta completely fused to segment. Palp reduced, one-segmented, with one short, slender seta and two long, bipinnate setae; two long setae subequal in length, ca $10 \times$ as long as shorter one.

MAXILlule (Fig. 12D). Three-segmented, composed of robust praecoxa and two-segmented maxillulary palp, representing coxobasis and enp. Arthrite of praecoxa with three strong claw-like extensions apically and one spinulose seta sub-apically. Praecoxa with seven elements along medial margin; proximalmost seta minute, sub-proximal seta robust and spinulose, three middle setae slender and smooth, sub-distal seta robust and smooth, distalmost seta robust and spinulose. Basal segment of palp with three elements apically; outer apical seta robust and armed with long spinules on outer margin; inner apical and subapical ones smooth. Exp reduced, represented by spinulose seta near lateral segment of palp. Enp represented by lateral segment of palp, with two setae apically and one seta sub-apically; all setae spinulose, subequal in length.

Maxilla (Fig. 12E). Five-segmented. Praecoxa and coxa partly fused frontally. Praecoxal endite prominent, inserted medially, with one smooth and one spinulose setae apically. Coxa with two endites; proximal endite with one smooth seta apically; distal endite rectangular, movable, with two spinulose setae apically; spinules on proximal seta of distal endite relatively long, those of distal one minute. Basis with claw-like endite and two setae at base of claw; longest seta strong, inserted ventrally to claw; shorter one slender, inserted on caudal surface above the longest seta; concave margin of claw with oblique row of spinules; spinules fused to basis and increased in size from frontal spinule to caudal one. Enp twosegmented; enp-1 with two robust setae; enp-2 with strong seta apically and two smooth, slender setae sub-apically.

MAXILLIPED (Fig. 12F). Four-segmented, composed of syncoxa, basis and two-segmented enp. Syncoxa with two endites and ornamented with arch row of spinules on outer margin; proximal endite with two subequal spinulose setae apically; distal endite with one spinulose seta. Basis with one seta on caudal surface; basal endite with one spinulose seta apically, with a row of long spinules on frontal surface. Enp-1 with strong spinulose seta. Enp-2 with three setae; apical seta strong, two other ones slender and smooth. 

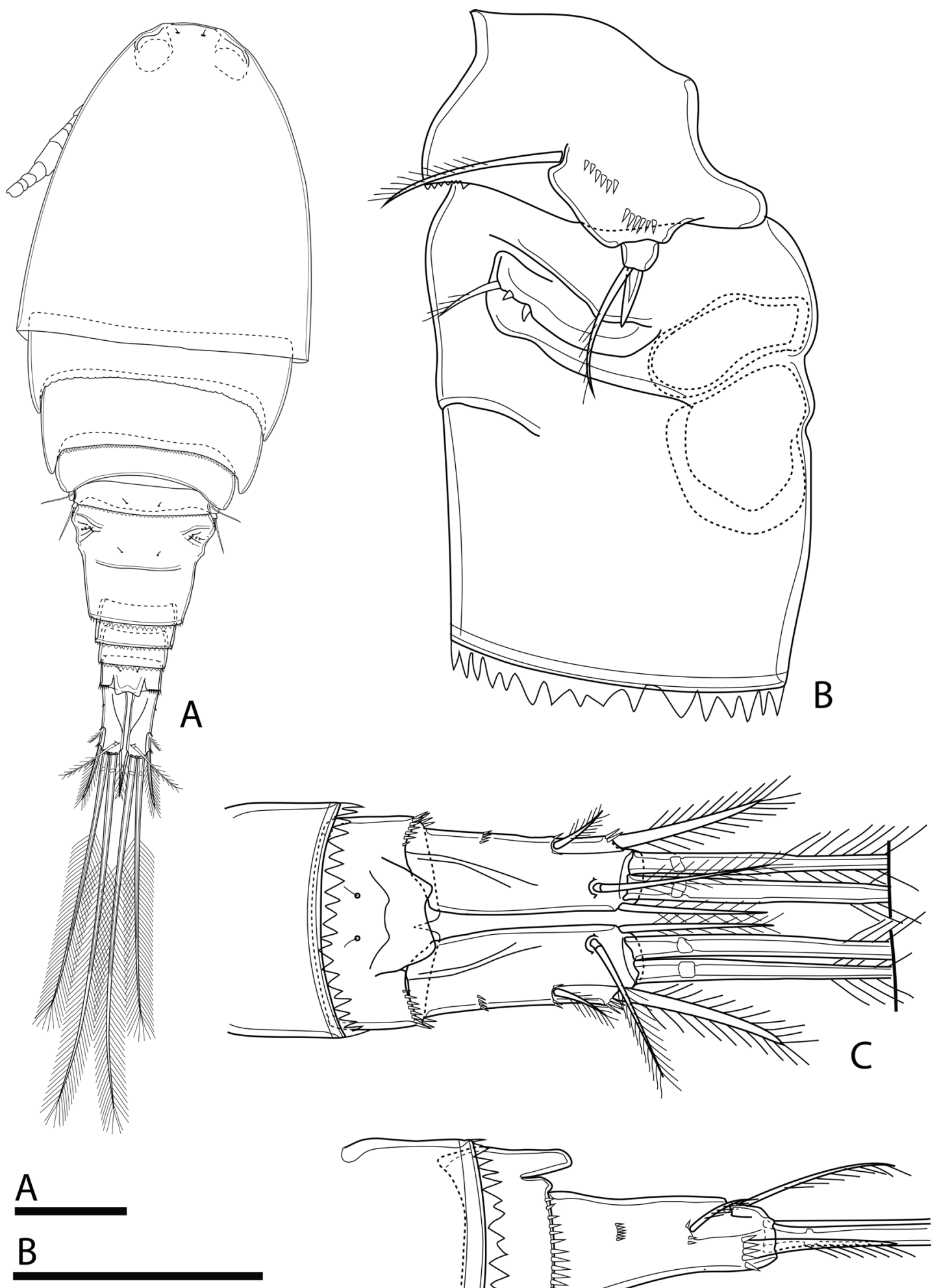

C-D

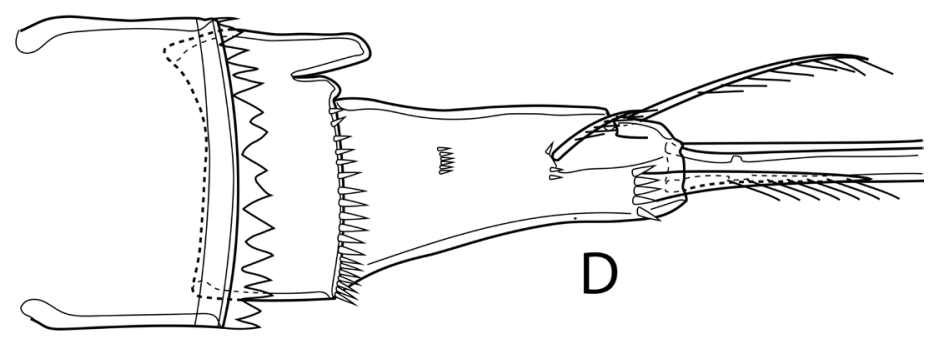

Fig. 10. Metacyclops brancelji sp. nov., paratype, $q$ (A; ZMB 34231a) and holotype, $q$ (B-D; ZMB 34231 slide No. 5124). A. Habitus, dorsal view. B. Fifth pedigerous somite and genital double-somite, lateral view. C-D. Two last abdominal somites and caudal rami, dorsal and lateral views, respectively. Scale bars: $\mathrm{A}=100 \mu \mathrm{m} ; \mathrm{B}-\mathrm{D}=50 \mu \mathrm{m}$. 
P1-P4 (Fig. 13). Two-segmented enp and exp. Intercoxal sclerite of P1 with few spinules on distal prominences, those of P2-P4 with 3-6 smaller spinules. Coxa with one seta on distal inner corner. Basis with one seta laterally and hairy medially. Setal and spine formulae of exp-2 of P1-P4: 5.5.5.5 and 3.4.4.3, respectively. Armature of swimming leg as in Table 1.

P1 (Fig. 13A). Frontal and caudal surfaces of intercoxal sclerite bare; distal prominence with $2-3$ spinules. Lateral seta on basis ca $4 \times$ as long as those of P2-P4; inner seta pinnate, reaching mid of enp-2. Exp-1 with outer spine and inner seta. Exp-2 as long as wide, with three spines and five setae; apical spine ca $0.71 \times$ as long as segment. Enp- 1 with inner seta. Enp- 2 ca $1.5 \times$ as long as wide, with outer seta inserted between claw-like expansion, apically with robust spine and seta, inner margin with three setae; outer seta ca $1.3 \times$ as long as length of apical spine; apical spine strong, slightly curved, as long as segment.
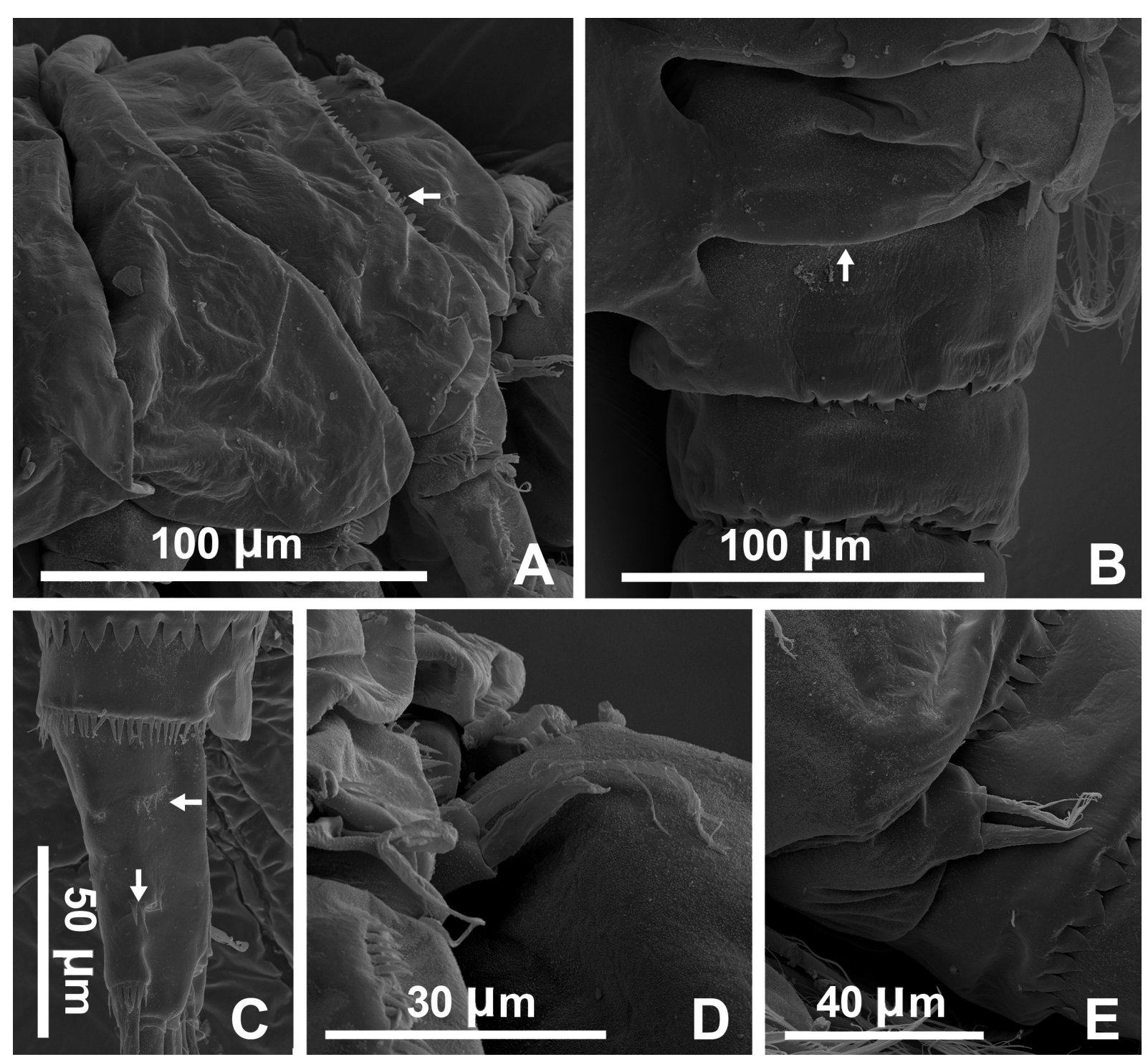

Fig. 11. Metacyclops brancelji sp. nov., SEM photographs of additional material (Rakhang Thong Cave, Satun Province, collection of the third author CB), $\widehat{O}(\mathrm{~A}, \mathrm{C}-\mathrm{E})$ and $q$ (B). A. Second and third pedigerous somites, lateral view (arrow indicates distal margin of third pedigerous somites). B. Genital double-somite and second abdominal somite, dorsal view (arrow indicates posterior margin of the transverse suture). C. Caudal ramus, lateral view (arrows indicate spinules). D. P5, lateral view. E. Male P6, lateral view. 


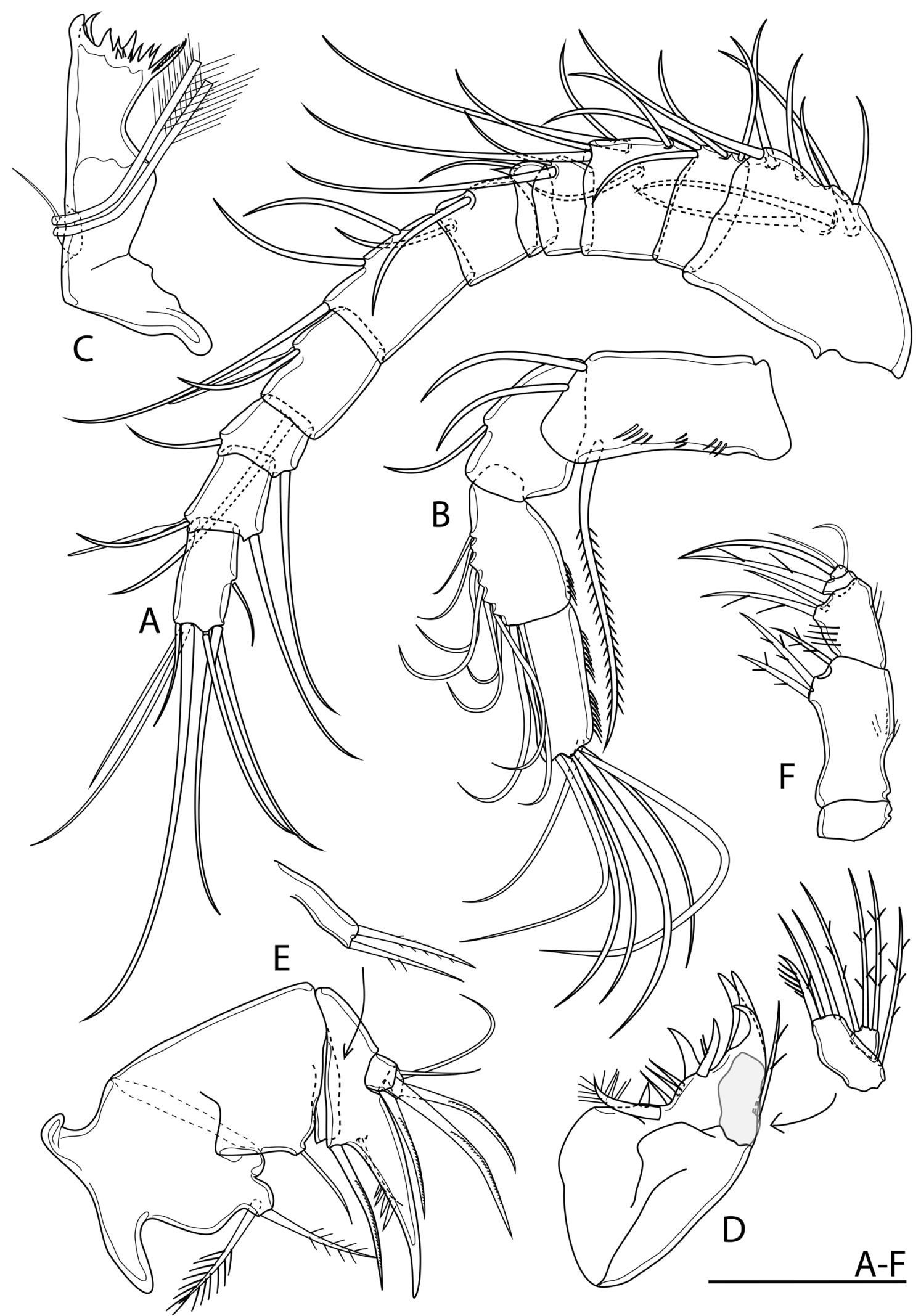

Fig. 12. Metacyclops brancelji sp. nov., holotype, $\varnothing_{\text {(ZMB }} 34231$ slide No. 5124). A. Antennule. B. Antenna, caudal view. C. Mandible. D. Maxillule, frontal view. E. Maxilla, frontal view. F. Maxilliped, frontal view. Scale bar $=50 \mu \mathrm{m}$. 

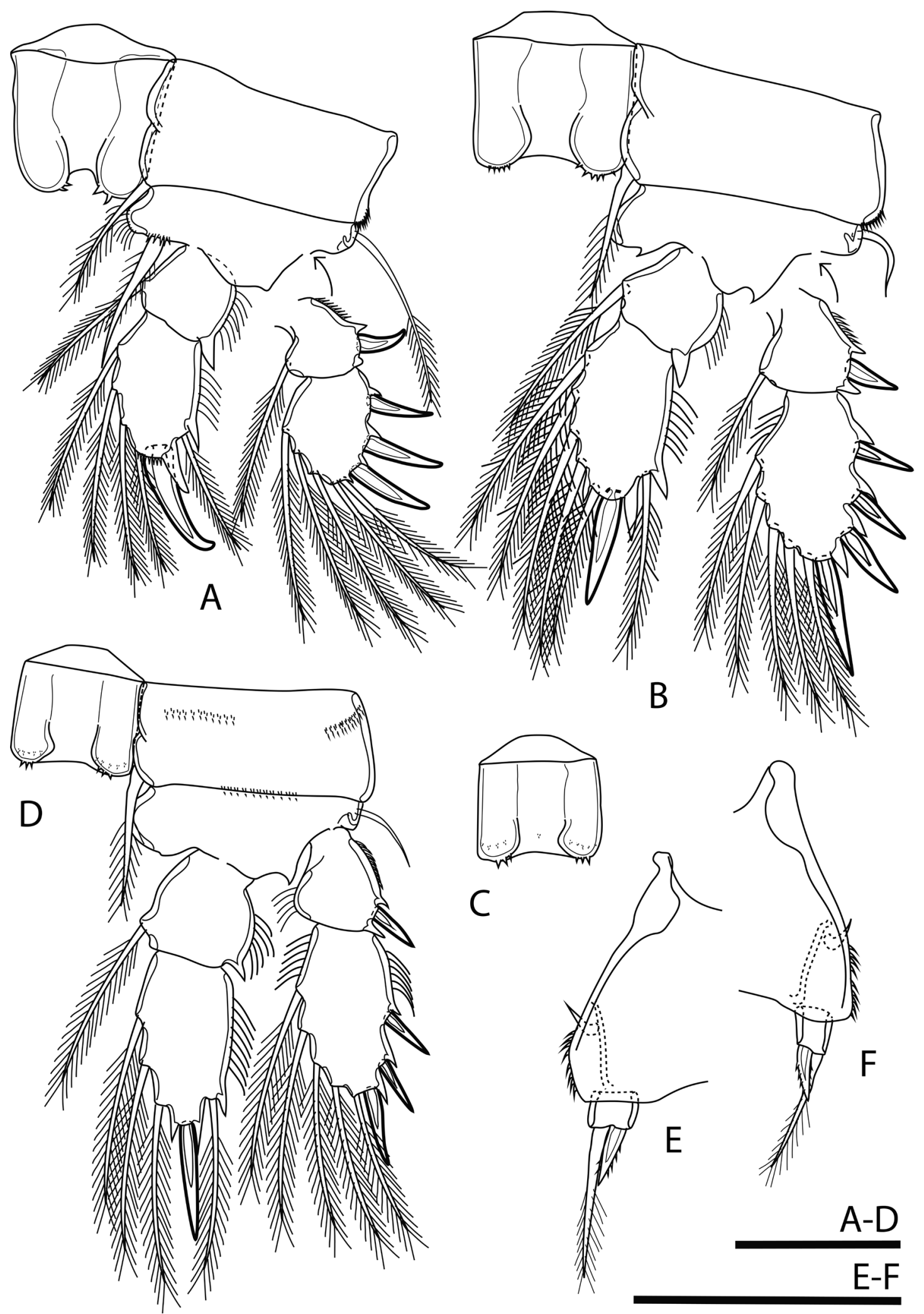

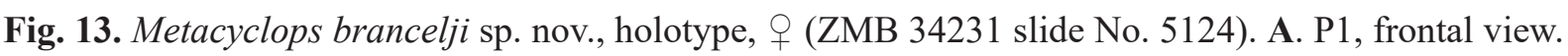
B. P2, frontal view. C. Frontal view of intercoxal sclerite of P3. D. P4, frontal view. E-F. Right and left $\mathrm{P} 5$, respectively, ventral view. In $\mathrm{C}-\mathrm{D}$, the spinule row is on the caudal surface of intercoxal sclerite and coxa. Scale bars $=50 \mu \mathrm{m}$. 
P2 (Fig. 13B). Intercoxal sclerite as in P1, with 4-5 spinules on distal prominence. Basis with two hooklike expansions: outer expansion located between insertions of exp and enp; inner one smaller, located at the same place where the medial seta of basis of P1 inserted. Lateral seta on basis ca $0.25 \times$ as long as that of P1. Exp-1 with outer spine and inner seta. Exp- 2 ca $1.5 \times$ as long as wide, with four spines and five setae; apical spine slightly shorter than segment. Enp-1 with inner seta. Enp-2 ca $1.7 \times$ as long as wide, with outer seta inserted between claw-like expansion, apically with robust spine and seta, inner margin with four setae; outer seta ca $1.3 \times$ as long as length of apical spine; apical spine strong and straight, as long as segment.

P3. Frontal surface of intercoxal sclerite bare; caudal surface with transversal row of minute spinules and distal prominences with 4-6 minute spinules (Fig. 13C). Basis, exp, and enp similar to those of P2.

P4 (Fig. 13D). Intercoxal sclerite similar to that of P3; yet distal prominences with 3-4 spinules. Distal margin of coxa with rows of spinules on caudal surface. Basis similar to those of P2 and P3. Exp-1 with outer spine. Exp- 2 ca $1.4 \times$ as long as wide, with three spines and five setae; spines relatively smaller than those of P1-P3, apical spine ca $0.5 \times$ as long as segment. Enp-1 with inner seta. Enp-2 ca 1.7 as long as wide, with outer seta inserted between claw-like expansion, apically with robust spine, inner margin with four setae; outer seta ca $1.3 \times$ as long as length of apical spine; apical spine ca $0.9 \times$ as long as segment.

P5 (Fig. 13E-F). One-segmented, inserted on postero-lateral corner of fifth pedigerous somite. Proximal segment completely fused to somite, represented by lateral seta. Distal segment free, subquadrate, ca $1.1 \times$ as long as wide, with one slender outer seta and one inner spine apically; inner spine ca $1.5 \times$ as long as segment and outer seta ca $2.5 \times$ as long as inner spine.

P6 (Figs 10B, 11B). Small, forming simple cuticular plate inserted latero-dorsally on genital doublesomite, and armed with one seta dorsally and two minute spiniform setae ventrally.

\section{Adult male}

Total body length, excluding caudal seta, $0.71-0.76 \mathrm{~mm}$ (mean $0.74 \mathrm{~mm} ; \mathrm{n}=3$; allotype $=0.71 \mathrm{~mm}$ ) (Fig. 14A). Habitus smaller and slenderer than in female. Naupliar eye and rostrum as in female. Prosome ca $62 \%$ of body length and ca $1.57 \times$ as long as length of urosome. Cephalothorax anteriorly oval, representing ca $32 \%$ of body length and ca $1.12 \times$ as long as wide. Second to fifth pedigerous somites similar to those of female. Genital somite swollen on mediolateral margin (Fig. 14A-B); ca 25\% length of urosome and ca $0.6 \times$ as long as wide, with hyaline frill latero-dorsally. First abdominal somite and two subsequent somites narrower than genital somite, ca $60 \%$ of genital somite width, with serrated hyaline frill on posterior margin. Anal somite and operculum similar to those of female.

Caudal Rami. As long as that in female, ca $2.7 \times$ as long as wide. Armament and ornamentation similar to those of female. Length ratio of caudal setae to ramus length slightly different to that of female; ratio of caudal setae to ramus length from seta II to seta VII: 0.29: 0.82: 3.94: 5.50: 0.70: 0.97 .

AnTENNUle (Fig. 14C-E). 16-segmented, geniculate. Armature formula as follows: 1-[8+3ae], 2-[4], 3-[2], 4-[2+ae], 5-[1], 6-[2], 7-[2], 8-[2], 9-[1+ae+I], 10-[2], 11-[2], 12-[I], 13-[2+ae], 14-[0], 15-[1], $16-[12]$. Eleventh and thirteenth segments with pinnate seta each.

AntenNa, mandible, MaXillule, MaXilla, MaXilliped. Similar to those of female.

P1. Frontal and caudal surfaces of intercoxal sclerite bare and distal prominences with 2-3 minute spinules (Fig. 15A). Coxa, basis, enp and exp similar to those of female. 


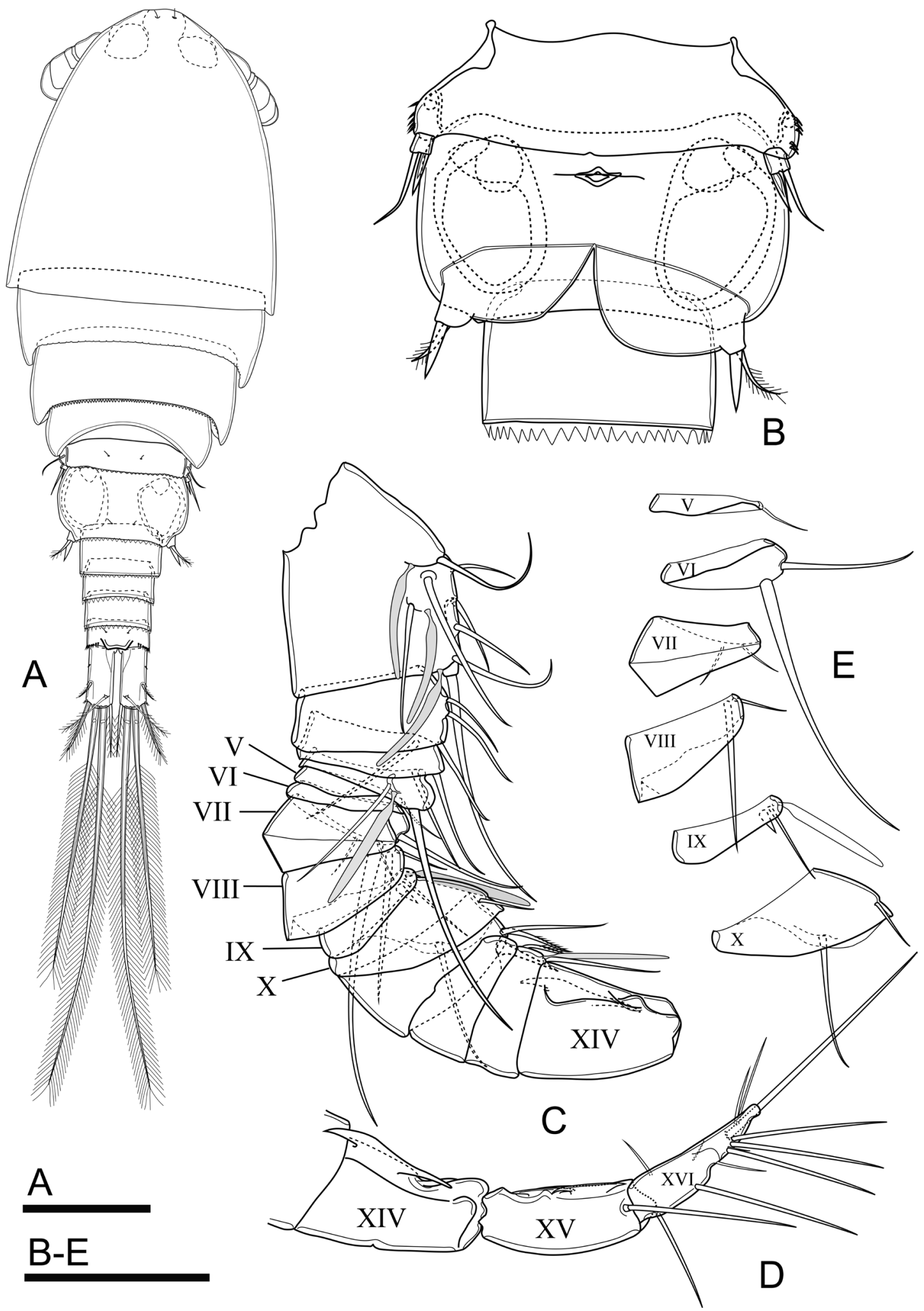

Fig. 14. Metacyclops brancelji sp. nov., paratype, $\widehat{\jmath}$ (A; ZMB 34231 slide No. 5126), allotype, $\widehat{\partial}$ (B-C, E; ZMB 34231 slide No. 5125) and additional material, ô (D; ZMB 34231 slide No. 5129). A. Habitus, dorsal view. B. Genital and first abdominal somites, ventral view. C. First to fourteenth segment of antennule. D. Fourteenth to sixteenth segment of antennule, E. Fifth to tenth segment of antennule (Roman numerals indicate segment of antennule). Scale bars: $A=100 \mu \mathrm{m} ; \mathrm{B}-\mathrm{E}=50 \mu \mathrm{m}$. 
P2. Intercoxal sclerite as in P1, distal prominences with 4-5 minute spinules (Fig. 15B). Coxa, basis, enp and exp similar to those of female.

P3. Frontal surface of intercoxal sclerite bare, caudal one with transversal row of minute spinules and distal prominences with 4-5 minute spinules (Fig. 15C). Coxa, basis, enp and exp similar to those of female.

P4. Frontal surface of intercoxal sclerite bare, caudal one with transverse row of minute spinules and distal prominences with 3-4 minute spinules (Fig. 15D). Coxa, basis, enp and exp similar to that of female; apical spine on enp- 2 ca $0.8 \times$ as long as segment.

P5 (Figs 11D, 14B, 15E-F). Similar to that of female. Free segment ca $1.1 \times$ as long as wide, with one slender outer seta and one inner spine apically; inner spine strong, ca $1.5 \times$ as long as segment bearing it; outer seta ca $2.5 \times$ as long as inner spine.

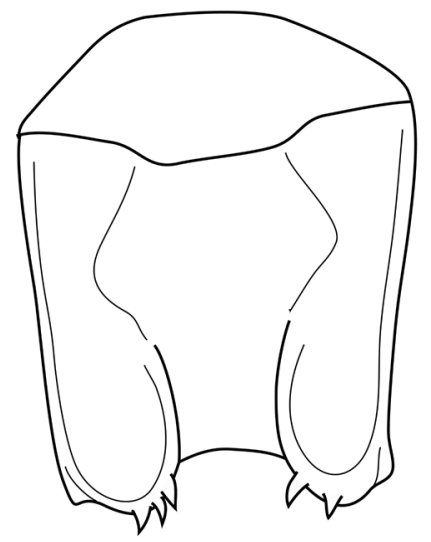

A

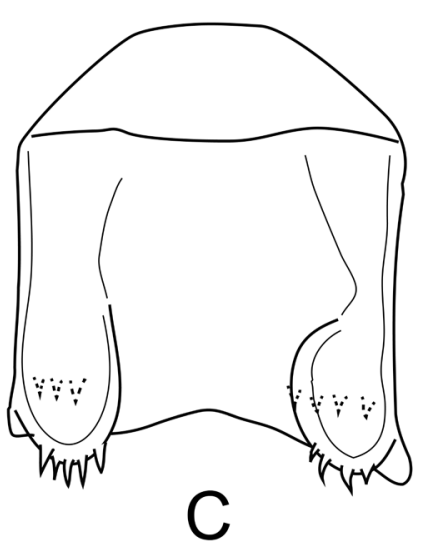

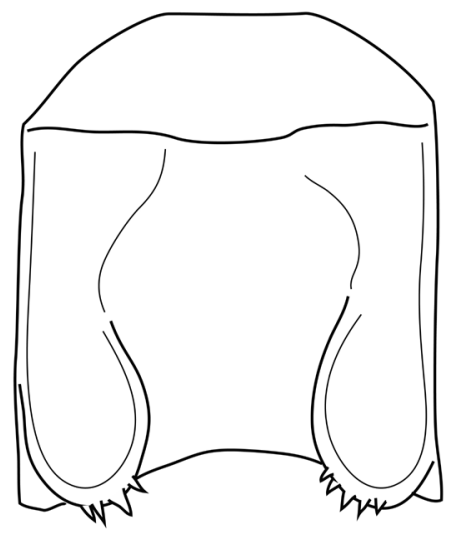

B

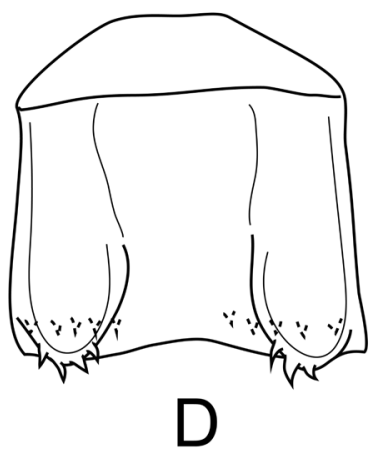

$\mathrm{D}$
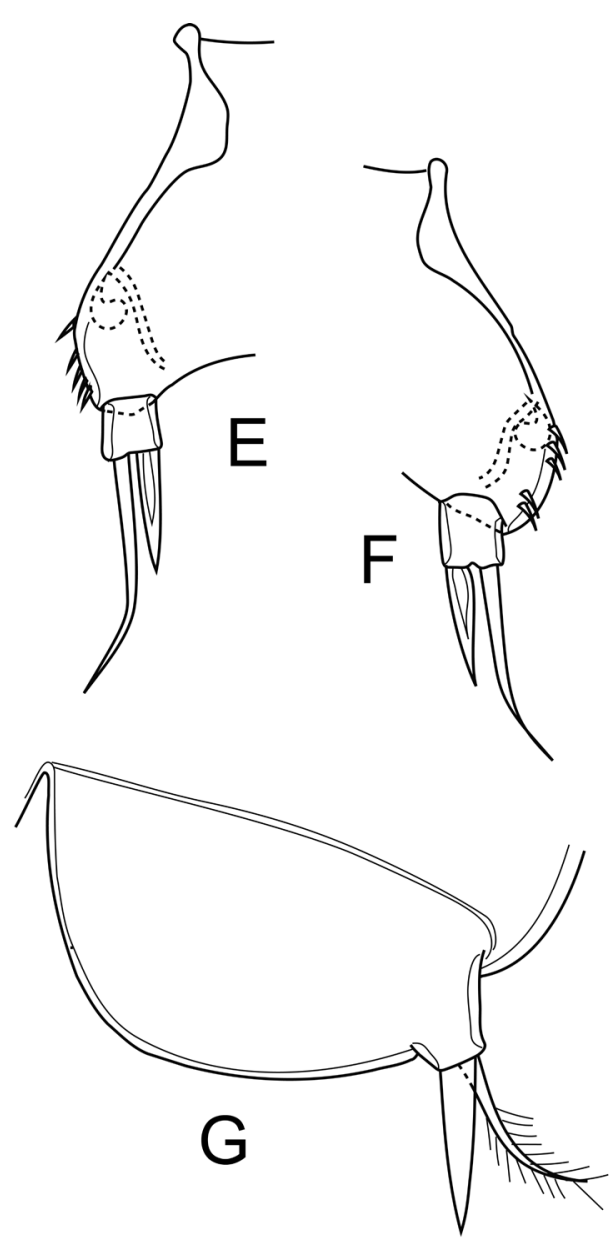

A-G

Fig. 15. Metacyclops brancelji sp. nov., paratype, $\widehat{\partial}$ (A-D; ZMB 34231 slide No. 5127) and allotype, $\widehat{\partial}$ (E-G; ZMB 34231 slide No. 5125). A-D. Intercoxal sclerites of P1, P2, P3 and P4, respectively, frontal view. E-F. Right and left P5, respectively, ventral view. G. P6, ventral view. In C-D, the spinule row is on the caudal surface of intercoxal sclerite. Scale bar $=50 \mu \mathrm{m}$. 
P6 (Figs 11E, 14B, 15G). Reduced to cuticular plate with two elements; inner spine strong, slightly shorter than outer seta.

\section{Variability}

The female specimens collected in Phupha Phet Cave are slightly smaller $(0.89 \mathrm{~mm}$ each, $\mathrm{n}=2)$ than those of Rakhang Thong Cave $(0.95-0.96 \mathrm{~mm}, \mathrm{n}=2)$ and Khao Nui Cave $(0.95-0.96 \mathrm{~mm}, \mathrm{n}=2)$. Similarly, the male specimens collected in Phupha Phet Cave $(0.71 \mathrm{~mm}, \mathrm{n}=1)$ are smaller than those of Rakhang Thong Cave $(0.75-0.76 \mathrm{~mm}, \mathrm{n}=2)$. Unfortunately, because the male has not yet been encountered from Khao Nui Cave, the length of the male is doubtful for this cave. Minor variation in the length/width ratio of the caudal rami, the length of spines of the female P5 and the male P6 are shown in Table 2.

\section{Distribution}

Metacyclops brancelji sp. nov. was encountered in three caves: Phupha Phet Cave and Rakhang Thong Cave (Satun Province; Fig. 1D-G), and Khao Nui Cave (Songkhla Province; Fig. 1D, H).

\section{Habitat}

Metacyclops brancelji sp. nov. was collected during the rainy season from temporary water bodies which are seasonally filled primarily by water from the epikarst zone of the cave. Specimens were collected by hand net from both a large pool $(n=53)$ and a rimstone $(n=10)($ Fig. $1 E-F)$, about 100 meters from the entrance of Phupha Phet Cave. The type locality is in the dark zone where the temperature is relatively constant. Based on four sampling occasions from December 2014 to December 2015, the temperature in the dark zone of Phupha Phet Cave varied from $24.4^{\circ} \mathrm{C}$ in July 2015 to $27.8^{\circ} \mathrm{C}$ in April 2015. In Khao Nui Cave, the new species was collected in December 2014 from a water body filled by dripping water $(n=4)$ at the deepest part of the twilight zone, about 20 meters from the entrance (Fig. 1H). In Rakhang Thong Cave, the new species was collected in July 2015 from a rimstone $(n=33)$ at the cave entrance. The entrance of Rakhang Thong Cave is located at the base of the hill. The area in front of the entrance is a rock shelter which has been modified for religious propose. Near the rimstone is a Buddha statue and the gutter was created to collect water from the top of the shelter above the rimstone (Fig. 1G). These let us hypothesize that the discovery of $M$. brancelji sp. nov. in the rimstone of Rakhang Thong Cave is accidental and the new species could be encountered in water bodies around the hill and in the cave, like in Phupha Phet Cave and Khao Nui Cave. Furthermore, if compared to the regional distribution of the three latest described copepod species in Satun Province, including Onychocamptus satunensis Boonyanusith, Saetang, Wongkamhaeng \& Maiphae, 2018, Boholina laorsriae Boonyanusith, Wongkamhaeng \& Athibai, 2020 and Rangabradya (Siamorangabradya) wongkamhaengae Boonyanusith \& Athibai, 2021, the distribution of $M$. brancelji sp. nov. is wider since it was collected in three separate caves located along the south of the mountain range, while the three above-mentioned species were only encountered in a single cave. The characteristics mentioned above suggest a stygophylic nature of $M$. brancelji sp. nov. rather than stygophilic, as suggested by many authors that stygophile exhibits an adaptation to spend their whole life and reproduce in subterranean habitats and can live in epigean environments (Galassi 2001; Sket 2008; Brancelj 2015).

\section{Differential diagnosis and remarks}

Currently, four different types of spine formula of enp-2 of P1-P4 have been recognized within the genus Metacyclops (Mercado-Salas et al. 2013). Most of the species (54) and two Thai new species have the type of spine formula of 3.4.4.3. Two species, including M. thailandicus from Thailand and M. cushae Reid, 1991 from Louisiana (USA), bear a spine formula of 3.4.3.3. Metacyclops mortoni Pesce, De Laurentiis \& Humphreys, 1996 is the only species that bears a spine formula of 3.4.4.2. The last type of spine formula is 3.3.3.3, represented by two species comprising M. trispinosus Dumont, 1981 from Africa and M. margaretae (Lindberg, 1938) from India (Karanovic 2004a, 2004b; Karanovic et al. 2011). 
Among the species with a 3.4.4.3 formula, M. sakaeratensis sp. nov. and M. brancelji sp. nov. most closely resemble the Cambodian M. woni Lee \& Chang, 2015. Based on characteristics described by Lee \& Chang (2015) for $M$. woni, the two Thai new species and $M$. woni share the combination of the following characteristics, including:

(1) female antennules 11-segmented

(2) posterior margin of second pedigerous somite undulated

(3) P4 enp-2 with one apical spine

(4) seta VI of caudal ramus shorter than seta III

(5) caudal rami with spinules at anterior third length of lateral surface

(6) male P6 bearing 2 elements

However, the two new species can be easily distinguished from $M$. woni by having: 1) transverse suture representing the remnant of ancestral articulation on the dorsal surface of the genital double-somite (absent in $M$. woni; Chang pers. com.), 2) serrated hyaline frill on the posterior margin of the third thoracic somite (absent in M. woni), 3) different length/width ratio of the caudal ramus (ca $2.3 \times$ in M. sakaeratensis sp. nov. and ca $2.7 \times$ in $M$. brancelji sp. nov. vs ca $2.5 \times$ in $M$. woni), and 4 ) a row of spinules on the intercoxal sclerite of P3 (absent in M. woni) (Table 2).

The armature of P5 and P6 are additional characters, separating the species (Table 2). In M. sakaeratensis sp. nov. and M. woni, the inner spine of P5 is minute, as long as the free segment, whereas it is ca $1.5 \times$ as long as the segment in M. brancelji sp. nov. Conversely, the inner spine of male P6 is subequal in length with the outer seta in M. brancelji sp. nov. and M. woni, while it is much shorter in M. sakaeratensis sp. nov. Additionally, in M. sakaeratensis sp. nov. there are 2-3 spinules in the row of spinules on the anterior third of the lateral surface of the caudal ramus, while in $M$. brancelji sp. nov. and $M$. woni the row of spinules is composed of 4-5 spinules. Other differences between the two new species and $M$. woni are listed in Table 2.

As suggested by Lee \& Chang (2015), the combination of the following characteristics, including 11-segmented antennule, spine formula of enp-2 of P1-P4 3.4.4.3, and P4 enp-2 bearing one single apical spine, are present in twelve other species, including M. communis (Lindberg, 1938), M. curtispinosus Dussart, 1984, M. denticulatus Dussart \& Frutos, 1985, M. deserticus Mercado-Salas \& Suárez-Morales, 2013, M. grandispinifer (Lindberg, 1940), M. hannensis Defaye, 1992, M. lusitanus Lindberg, 1961, M. malayicus (Kiefer, 1930), M. minutus (Claus, 1863), M. minutus prolatus (Kiefer, 1935), M. pectiniatus Shen \& Tai, 1964, and M. subdolus Kiefer, 1938 (Lee \& Chang 2015). However, in the two new species the length/width ratio of the caudal ramus is shorter than 3, while it is longer than 3 in M. communis (3-4; Lindberg 1940), M. deserticus (3.5-3.8; Mercado-Salas et al. 2013), M. grandispinifer (3.7-5.7; Lindberg 1940), M. hannensis (3.2-3.4; Defaye 1992; Mercado-Salas et al. 2013), M. lusitanus (ca 3.75; Lindberg 1961; Herbst 1988), M. minutus (4-5; Tai \& Chen 1979), M. prolatus (4.5-5.5; Dussart 1982; Lindberg 1961), and M. pectiniatus (3.4-3.5; Herbst 1988). According to Kiefer (1930), the caudal ramus's length/width ratio is ca 2 in M. malayicus. It is less than that in M. sakaeratensis sp. nov. (ca 2.3) and M. brancelji sp. nov. (ca 2.7). Based on the key of Herbst (1988), the length/width ratio of the caudal ramus is more or less similar to both new species in M. subdolus (2.7-3.4), M. denticulatus (2.7-2.8), and M. curtispinosus (2.4-2.8) (Mercado-Salas et al. 2013; Herbst 1988; Defaye \& Por 2010; Pesce 1978). Nevertheless, the seta III of the caudal ramus is shorter than seta VI in M. curtispinosus and M. subdolus. In comparison, the seta III is longer than the seta VI in the two Thai new species. In M. denticulatus, the seta VI approximately reaches the middle of the length of the seta III (Dussart \& Frutos 1985), while they are subequal in length in the two Thai new species.

Previously, Lee \& Chang (2015) argued that the ornamentation of the spinule on the anterior third of the lateral surface of the caudal ramus is very characteristic for $M$. woni, but we realized that it has 
previously been described or illustrated in many Brazilian species of Metacyclops, such as M. campestris Reid, 1987, M. hirsutus Rocha, 1994, M. oraemaris Rocha, 1994, M. paludicola (Herbst, 1959), and in M. ryukyuensis Ishida, 1995 from Japan (Reid 1987; Rocha 1994; Ishida 1995). However, the two new species and $M$. woni differ from M. campestris, M. hirsutus, M. oraemaris, and M. paludicola by having one apical spine on P4 enp-2 instead of two apical ones. Both new species and M. woni share several characters with $M$. ryukyuensis but the Japanese species could be easily distinguished from the new species by having 12-segmented antennule (vs 11-segmented antennule in both new species) and seta III shorter than seta VI (vs seta III longer than seta VI in the two new species).

Currently, only M. thailandicus has been described from Thailand (Boonyanusith et al. 2018b). Both new species are distinguishable from $M$. thailandicus, according to the differences in the following characters: 1) spine formula of enp-2 of $\mathrm{P} 1-\mathrm{P} 4$ (3.4.4.3 in both new species vs 3.4.3.3 in M. thailandicus), 2) ornamentation on the intercoxal sclerite of P1-P4 (with spinule ornamentation in both new species vs without spinule ornamentation in $M$. thailandicus), 3) relative length of the seta representing exp of antenna (reaching tip of enp-3 of antenna in both new species vs short, not reaching tip of enp-3 of antenna in M. thailandicus, 4) armament of the antenna (setal formula 3.1.9.7 in both new species vs 3.1.5.7 in M. thailandicus, and 5) length ratio of the outer seta to the apical spine on P4 enp-2 (1.3 in the new species vs 2.7 in $M$. thailandicus). Furthermore, the distinct feature of the transverse suture on the dorsal surface of the genital double-somite is an additional characteristic that distinguishes the two Thai new species from M. thailandicus. In M. thailandicus, the transverse suture is discontinuous and separated into two lateral sutures, while it is continuous in the new species.

\section{Identification key to the female of Metacyclops species recorded in Asia}

Thirteen species of Metacyclops have been recorded in Asia, excluding M. sakaeratensis sp. nov. and M. brancelji sp. nov. (Dussart \& Defaye 2006; Kołaczyński 2015; Lee \& Chang 2015; Boonyanusith et al. 2018b). Most of them have spines on the exp-2 of P1-P4 in the formula of 3.4.4.3, with one single apical spine on P4 enp-2, and only M. gracilis (Lilljeborg, 1853) bear two apical spines on P4 enp-2. At the regional-scale, four species have been recorded in Western Asia (M. gracilis, M. planus (Gurney, 1909), M. amoenus (Mann, 1940), and M. minutus), five in Southern Asia (M. margaretae, M. gracilis, M. grandispinifer, M. minutus, and M. communis), four in Eastern Asia (M. ryukyuensis, M. pectiniatus, M. minutus, M. gracilis), and six in Southeast Asia (M. minutus, M. pectiniatus, M. malayicus, M. woni, M. amicitiae, $M$. thailandicus). Based on zoogeographical perspective, five species have been recorded in the Palaearctic region (Turkey, Mongolia, China: Guangdong, Israel, Syria, Iran, Pakistan, Afghanistan, Iraq, Lebanon) and eleven species in the Oriental region (Japan: Ryukyu, Vietnam, Thailand, Cambodia, Indonesia: Sumatra, Malaysia, India, Sri Lanka). Furthermore, most of them were known before 1940, while all the most recently described species were from Southeast Asia (M. amicitiae, M. thailandicus, M. woni) increased interest in the diversity of Copepoda in this region (Kołaczyński 2015; Lee \& Chang 2015; Boonyanusith et al. 2018b). For this reason, an up-to-date key to the female of these species is provided hereafter.

1. Spine formula of exp-2 of P1-P4 3.3.3.3

- Spine formula of exp-2 of P1-P4 3.4.3.3

M. margaretae (Lindberg, 1938) [India]

M. thailandicus Boonyanusith, Sanoamuang \& Brancelj, 2018 [Thailand]

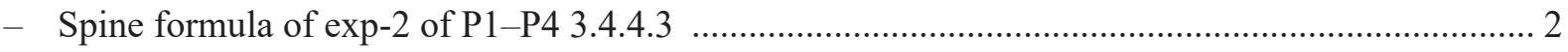

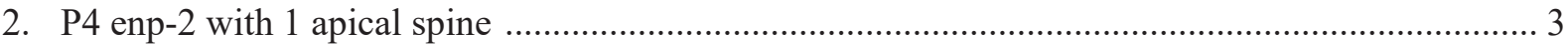

- P4 enp-2 with 2 apical spines ..................... gracilis (Lilljeborg, 1853) [Turkey, Mongolia, India]

3. Antennule 9-segmented ............................................. planus (Gurney, 1909) [Israel, Syria, Iran]

- Antennule 10-segmented M. amoenus (Mann, 1940) [Turkey] 


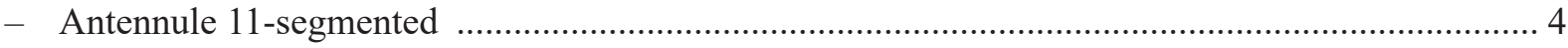

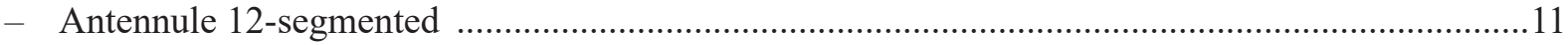

4. Seta III shorter than seta VI ................................. malayicus (Kiefer, 1930) [Indonesia: Sumatra]

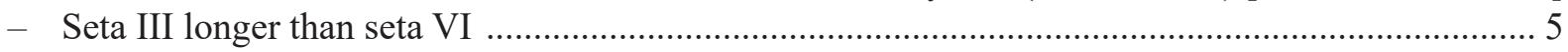

5. Apical spine on P4 enp-2 as long as or longer than segment bearing it ........................................ 6

- Apical spine on P4 enp-2 shorter than segment bearing it ...................................................... 8

6. Caudal ramus $4 \times$ as long as wide or more than $4 \times$ as long as wide

M. minutus (Claus, 1863) [Afghanistan, China, Iraq, Israel, Lebanon, Malaysia, Southern Iran, Sri Lanka, Mongolia, Pakistan, Syria]

- Caudal ramus less than $4 \times$ as long as wide 7

7. Seta $\mathrm{V}$ of caudal ramus ca $1.3 \times$ as long as seta $\mathrm{IV}$ M. communis (Lindberg, 1938) [India]

- Seta V of caudal ramus at least ca $1.5 \times$ as long as seta IV M. pectiniatus Shen \& Tai, 1964 [China, Malaysia]

8. Caudal ramus $3 \times$ as long as wide or more than $3 \times$ as long as wide

M. grandispinifer (Lindberg, 1940) [India, Turkey, Iran]

- Caudal ramus always less than $3 \times$ as long as wide

9. Genital double-somite with transverse suture, representing remnant of ancestral articulation ...... 10

- Genital double-somite without transverse suture M. woni Lee \& Chang, 2015 [Cambodia]

10. Apical spine of P5 ca $1.5 \times$ as long as segment bearing it; caudal ramus ca $2.7 \times$ as long as wide in female M. brancelji sp. nov. [Thailand]

- Apical spine of P5 as long as segment bearing it; caudal ramus ca $2.2 \times$ as long as wide in female . M. sakaeratensis sp. nov. [Thailand]

11. Intercoxal sclerite of $\mathrm{P} 1-\mathrm{P} 4$ with hairs on prominences and that of $\mathrm{P} 4$ with transversal row of spinule on caudal surface; enp-2 of antenna with nine setae ........ amicitiae Kołaczyński, 2015 [Vietnam]

- Intercoxal sclerite of P1-P4 without ornamentation; enp-2 of antenna with eight setae M. ryukyuensis Ishida, 1995 [Japan: Ryukyu Island]

\section{Discussion}

According to Defaye \& Por (2010), Karanovic et al. (2011), and Lee \& Chang (2015), M. sakaeratensis sp. nov. and M. brancelji sp. nov. should be classified within the genus Metacyclops based on the combination of the following characteristics:

(1) P1-P4 with two-segmented exp and enp

(2) setal and spine formulae of exp-2 of P1-P4 5.5.5.5 and 3.4.4.3, respectively

(3) P4 enp-2 with armature formula 1, I, 3

(4) P5 one-segmented, with spine and seta inserted close to each other

With the combination of the four above characteristics, the two new species are distinguishable from the other genera in which the P5 is reduced to a single segment bearing one inner spine and one outer seta, such as Apocyclops Lindberg, 1942, Muscocyclops Kiefer, 1937, Cochlacocyclops Kiefer, 1955, Goniocyclops Kiefer, 1955, Hesperocyclops Herbst, 1984, Fierscyclops Karanovic, 2004, Pibalacyclops Karanovic, 2006, Pescecyclops Karanovic, Eberhard \& Murdoch, 2011, and Meridiecyclops Fiers, 2001 (Fiers 2001; Pesce 1996; Dussart \& Defaye 2001; Karanovic et al. 2011; Boonyanusith et al. 2018b). However, if comparing the relative length of the seta representing exp to the enp of the antenna and the 
length ratio of the outer seta on $\mathrm{P} 4$ enp-2 to the apical spine, there exists a remarkable difference among the representatives of the genus Metacyclops. This difference will be described next.

Based on the original description of the three Asian species of Metacyclops (i.e., M. amicitiae, M. ryukyuensis, and $M$. woni) and two species in which $\mathrm{P} 4 \mathrm{enp}-2$ bears one single apical spine, including $M$. deserticus, and M. hannensis, as well as the two new species, the outer seta on P4 enp-2 is shorter than twice the length of apical spine of $\mathrm{P} 4$ enp-2, and the seta representing exp reaches the tip of enp-3 of antenna. The relative length of the outer seta on P4 enp- 2 and the seta representing exp of antenna are different from those of M. thailandicus and M. cushae in which the outer seta on P4 enp-2 is elongated, being longer than twice the length of the apical spine, and the seta representing exp of antenna is shortened, not reaching past the distal margin of enp- 2 of antenna. Although the seta representing exp of antenna is relatively short in some species, such as M. campestris Reid, 1987 and M. geltrudeae Galassi \& Pesce, 1994, or absent in some other species, such as M. gasparoi Stoch, 1987 and M. oraemaris, their outer seta of P4 enp-2 is shorter than twice the length of the apical spine (Stoch 1987; Rocha 1994; Galassi \& Pesce 1994). From this perspective, it is likely that the combination of these two characteristics would be a clue of the different phylogenetic lineage of $M$. thailandicus and $M$. cushae among the representatives of genus Metacyclops. This hypothesis is supported by the similarity of many characteristics in M. thailandicus and M. cushae and the characteristic of the male of the genus Hesperocyclops (Boonyanusith et al. 2018), combined with the previous phylogenetic consideration of Karanovic et al. (2011) which found that M. cushae was nested within the genus Hesperocyclops rather than within the genus Metacyclops. Nevertheless, because of an inadequacy of the original descriptions of many species, a revision should be undertaken based on both morphological and molecular phylogenetic works.

In Thailand, knowledge of freshwater Cyclopoida comes primarily from research efforts that aimed to collect zooplankton from various types of water bodies such as rivers, lakes, man-made reservoirs, rice fields, temporary pools, and irrigation channels (Bricker et al. 1978; Boonsom 1984; Sanoamuang 1999; Alekseev \& Sanoamuang 2006). Meanwhile, sampling of benthic and subterranean Copepoda in mountainous area has been overlooked. According to the great contributions of Professor Dr La-orsri Sanoamuang and Professor Dr Anton Brancelj on the diversity of copepod in caves and karsts in Thailand and Vietnam (e.g., Brancelj 2005; Brancelj et al. 2010; Tran \& Brancelj 2017; Sanoamuang et al. 2019; Koompoot \& Sanoamuang 2021; Sanoamuang \& Watiroyram 2021), the number of copepod species has increased rapidly. Recently, several new Cyclopoida and Harpacticoida were discovered in Thailand by them and their colleagues, including either known genera such as Atthyella Brady, 1880 (1 species), Elaphoidella Chappuis, 1929 (8 species), Onychocamptus Daday, 1903 (1 species), Bryocyclops Kiefer, 1927 (6 species), Fierscyclops Karanovic, 2014 (2 species), Metacyclops Kiefer, 1927 (1 species), Parapseudoleptomesochra Lang, 1965 (1 species), Thermocyclops Kiefer, 1927 (2 species), Schizopera Sars, 1905 (1 species) and the newly erected genus and subgenus, such as Siamcyclops Boonyanusith, Sanoamuang \& Brancelj, 2018 (1 species) and Rangabradya (Siamorangabradya) Boonyanusith \& Athibai 2021 (1 species) (Brancelj et al. 2010; Watiroyram et al. 2012, 2015a, 2015b, 2017, 2021; Boonyanusith et al. 2013; 2018a; 2018b; Watiroyram \& Brancelj 2016; Karanovic et al. 2017; Watiroyram 2018a, 2018b, 2021a, 2021b; Boonyanusith \& Athibai 2021; Koompoot \& Sanoamuang 2021; Sanoamuang \& Watiroyram 2021). Of the listed genera, Fierscyclops, Rangabradya, and Parapseudoleptomesochra were the first records in Southeast Asia (Boonyanusith et al. 2013; Boonyanusith \& Athibai 2021; Koompoot \& Sanoamuang 2021). Furthermore, a new species of the genus Boholina Fosshagen \& Iliffe, 1989, has more recently been described from freshwater pools in a cave, being the first record of stygobiotic Calanoida in Thailand (Boonyanusith et al. 2020).

Nevertheless, the diversity of Copepoda in Thai headwater streams is largely unknown. Until present, only three new species have been described from this habitat type in Thailand, including Afrocyclops henrii Alekseev \& Sanoamuang, 2006, Asiacaris dispar Cottarelli, Bruno \& Berera, 2010, and 
Kinnecaris iulianae Bruno \& Cottarelli, 2015 (Alekseev \& Sanoamuang 2006; Cottarelli et al. 2010; Bruno \& Cottarelli 2015). Yet due to the differences of local conditions (e.g., substrate type, water velocity) within a headwater stream there are an enormous array of habitats and the geographical isolation of such streams support genetically isolated species which contribute to the diversity of aquatic fauna at the catchment-scale (Gomi et al. 2002; Meyer et al. 2007). Therefore, research on zooplankton diversity in headwater streams should be encouraged to fill the gap of knowledge on copepod diversity not only in Thailand but also in Southeast Asia.

\section{Acknowledgements}

This research was financial supported by the Office of the Higher Education Commission, Thailand (2558A13562002), the Research and Academic Affairs Promotion Fund (RAAPF), Faculty of Science, Khon Kaen University, the Fiscal year 2017. The authors sincerely thank Rudy C.A.M. Jocqué, Radka Rosenbaumová, Nancy F. Mercado-Salas and an anonymous referee for his and her valuable revision of the manuscript.

\section{References}

Alekseev V.A. \& Sanoamuang L. 2006. Biodiversity of cyclopoid copepods in Thailand - with a description of Afrocyclops henrii sp. n. Arthropoda Selecta 15: 277-290.

Boonsom J. 1984. The freshwater zooplankton of Thailand (Rotifera and Crustacea). Hydrobiologia 113: 223-229. https://doi.org/10.1007/BF00026610

Boonyanusith C. \& Athibai S. 2021. A new species of Rangabradya (Copepoda, Harpacticoida, Ectinosomatidae) from a cave in Satun Province, southern Thailand. ZooKeys 1009: 45-66. http://doi.org/10.3897/zookeys.1009.54554

Boonyanusith C., Brancelj A. \& Sanoamuang L. 2013. First representatives of the genus Fierscyclops Karanovic, 2004 (Copepoda, Cyclopidae) from South East Asia. Journal of Limnology 72 (suppl.2): 275-289. https://doi.org/10.4081/jlimnol.2013.s2.e13

Boonyanusith C., Saetang T., Wongkamheng K. \& Maiphae S. 2018a. Onychocamptus Daday, 1903 from Thailand, with descriptions of two new species and two new records (Crustacea, Copepoda, Harpacticoida, Laophontidae). ZooKeys 810: 45-89. https://doi.org/10.3897/zookeys.810.29253

Boonyanusith C., Sanoamuang L. \& Brancelj A. 2018b. A new genus and two new species of cavedwelling cyclopoids (Crustacea, Copepoda) from the epikarst zone of Thailand and up-to-date keys to genera and subgenera of the Bryocyclops and Microcyclops groups. European Journal of Taxonomy 431: 1-30. https://doi.org/10.5852/ejt.2018.431

Boonyanusith C., Wongkamhaeng K. \& Athibai S. 2020. A new species of Boholina (Crustacea, Copepoda, Calanoida) and a first record for stygobiotic calanoid fauna from a cave in Thailand. ZooKeys 904: 1-22. https://doi.org/10.3897/zookeys.904.37609

Brancelj A. 2005. Hadodiaptomus dumonti n. gen., n. sp., a new freshwater stygobitic calanoid (Crustacea: Copepoda: Calanoida) from Vietnam (South Asia) and a new member of the subfamily Speodiaptominae Borutzky, 1962. Hydrobiologia 534: 57-70. https://doi.org/10.1007/s10750-004-1321-4

Brancelj A. 2015. The Velika Pasica Cave - The History, Environment and Life in It. ZRC Publishing and National Institute of Biology, Ljubljana.

Brancelj A., Watiroyram S. \& Sanoamuang L. 2010. The first record of cave-dwelling Copepoda from Thailand and description of a new species: Elaphoidella namnaoensis n. sp. (Copepoda, Harpacticoida). Crustaceana 83: 779-793. https://doi.org/10.1163/001121610X502894 
Bricker K.S., Wongrat L. \& Gannon J.E. 1978. Composition and distribution of crustacean plankton in twelve inland water bodies of Thailand. Kasetsart University Fisheries Research Bulletin 10: 1-14.

Bruno M.C. \& Cottarelli V. 2015. First record of Kinnecaris (Copepoda: Harpacticoida: Parastenocarididae) from Turkey and Thailand; description of three new species and emended definition of the genus. Italian Journal of Zoology 82: 1-26. https://doi.org/10.1080/11250003.2014.1002820

Cottarelli V., Bruno M.C. \& Berera R. 2010. First record of Parastenocarididae from Thailand and description of a new genus (Copepoda: Harpacticoida). Journal of Crustacean Biology 30: 478-494. https://doi.org/10.1651/09-3201.1

Defaye D. 1992. Metacyclops hannensis n. sp. (Crustacea, Copepoda, Cyclopoïda), un cyclopide nouveau du Sénégal. Revue d'Hydrobiologie Tropicale 25: 145-151.

Defaye D. \& Por F.D. 2010. Metacyclops (Copepoda, Cyclopidae) from Ayyalon Cave, Israel. Crustaceana 83: 399-423. https://doi.org/10.1163/001121610X12627655658320

Dussart B.H. 1982. Crustacés Copépodes des Eaux Intérieures. Faune de Madagascar 58, ORSTOM, Paris.

Dussart B.H. \& Defaye D. 2001. Introduction to the Copepoda. In: Dumont H.J.E. (ed.) Guides to the Identification of the Microinvertebrates of the Continental Waters of the World. Vol. 16. Backhuys Publishers, Leiden.

Dussart B.H. \& Defaye D. 2006. World Directory of Crustacea Copepoda of Inland Waters II Cyclopiformes. Backhuys Publishers, Leiden.

Dussart B.H. \& Frutos S.M. 1985. Sur quelques copépodes d'Argentine. Revue d'Hydrobiologie tropicale 18: $305-314$.

Fiers F. 2001. Meridiecyclops, gen. nov., a new cyclopid genus (Crustacea: Copepoda: Cyclopidae) from southern Australia. Invertebrate Taxonomy 15: 893-908. https://doi.org/10.1071/IT01003

Fiers F. 2012. The generic concept of Allocyclops Kiefer, 1932: (Copepoda: Cyclopoida: Cyclopidae) an alternative view. Journal of Natural History 46: 175-247. https://doi.org/10.1080/00222933.2011.626530

Galassi D.M.P. 2001. Groundwater copepods: diversity patterns over ecological and evolutionary scales. Hydrobiologia 453/454: 227-253. https://doi.org/10.1023/A:1013100924948

Galassi D.M.P. \& Pesce G.L. 1994. Metacyclops geltrudeae n. sp., a new cyclopid from ground waters of Venezuela (Copepoda, Cyclopidae). Crustaceana 67: 284-287. https://doi.org/10.1163/156854094X00387

Gomi T., Sidle R.C. \& Richardson J.S. 2002. Understanding processes and downstream linkages of headwater systems. BioScience 52: 905-916. https://doi.org/10.1641/0006-3568(2002)052[0905:UPADLO]2.0.CO;2

Huys R. \& Boxshall GA. 1991. Copepod Evolution. The Ray Society, London.

Herbst H.V. 1988. Zwei neue Metacyclops (Crustacea Copepoda) von den westindischen Inseln Barbados und Aroba: M. agnitis n. sp. und M. mutates n. sp., sowie ein Bestimmungschlüssil für das Genus. Bijdragen tot de Dierkunde 58: 137-154. https://doi.org/10.1163/26660644-05801011

Ishida T. 1995. A new species of Metacyclops (Crustacea, Copepoda, Cyclopoida) from Ishigaki Island, the Ryukyu Islands. Proceedings of the Japanese Society of Systematic Zoology 50: 6-12.

Karanivic T. 2004a. Subterranean Copepoda from Arid Western Australia. Crustaceana Monographs. Vol.3. Brill, Leiden. https://doi.org/10.1163/9789047412779

Karanovic T. 2004b. The genus Metacyclops Kiefer in Australia (Crustacea: Copepoda: Cyclopoida), with description of two new species. Records of the Western Australian Museum 22: 193-212.

https://doi.org/10.18195/issn.0312-3162.22(3).2004.193-212 
Karanovic T., Eberhard S.M. \& Murdoch A. 2011. A cladistic analysis and taxonomic revision of Australian Metacyclops and Goniocyclops, with description of four new species and three new genera (Copepoda, Cyclopoida). Crustaceana 84: 1-67. https://doi.org/10.1163/001121610X546698

Karanovic T., Koomput K. \& Sanoamuang L. 2017. Two new Thermocyclops species (Copepoda, Cyclopoida) from Thailand, with notes on the genus phylogeny inferred from 18S and ITS sequences. Zoologischer Anzeiger - A Journal of Comparative Zoology. 269: 26-47. http://doi.org/10.1016/j.jcz.2017.07.003

Kiefer F. 1930. Neue Cyclopiden von den Sunda-Inseln. (2. Mitteilung über die Cyclopiden der Deutschen Limnologischen Sunda-Expedition). Zoologischer Anzeiger 90: 55-58

Kołaczyński A. 2015. A new species of Metacyclops from a hyporheic habitat in North Vietnam (Crustacea, Copepoda, Cyclopidae). ZooKeys 522: 141-152. http://doi.org/10.3897/zookeys.522.5989

Koompoot K. \& Sanoamuang L. 2021. Parapseudoleptomesochra phayaoensis, a new species of copepod (Copepoda: Harpacticoida: Ameiridae) from a cave in northern Thailand. Invertebrate Zoology 18: 1-15. https://doi.org/10.15298/invertzool.18.1.01

Lee J.M. \& Chang C.Y. 2015. Metacyclops woni n. sp., a new cyclopoid species (Copepoda: Cyclopoida: Cyclopidae) from Cambodia. Animal Systematics Evolution and Diversity 31: 247-256. https://doi.org/10.5635/ASED.2015.31.4.247

Lindberg K. 1940. Cyclopides (Crustacés Copépodes) de l'Inde. IV. Une révision des réprésentants indiens et iraniens du sous-genre Metacyclops Kiefer, du genre Cyclops Müller. Records of the Indian Museum 42: 576-588.

Lindberg K. 1961. Remarques sur le genre Metacyclops (Kiefer, 1927) et description d'un Metacyclops nouveau du Portugal. Kunglige Fysiografiska Sällskapets i Lund Förhandlingar 31: 133-145.

Mercado-Salas N.F., Suárez-Morales E., Maeda-Martinez A.M. \& Silva-Briano M. 2013. A new species of Metacyclops Kiefer, 1927 (Copepoda, Cyclopidae, Cyclopinae) from the Chihuahuan desert, northern Mexico. ZooKeys 287: 1-18. http://doi.org/10.3897/zookeys.287.4358

Meyer J.L., Strayer D.L., Wallace J.B., Eggert S.L., Helfman G.S. \& Leonard N.E. 2007. The contribution of head water streams to biodiversity in river networks. Journal of the American Water Resources Association 40: 86-103. https://doi.org/10.1111/j.1752-1688.2007.00008.x

Pesce G.L. 1978. The occurrence of Metacyclops subdolus Kiefer (Crustacea, Copepoda) in subterranean waters of Greece with remarks on its systematic status. International Journal of Speleology 10: 179-183. https://doi.org/10.5038/1827-806X.10.2.4

Pesce G.L. 1996. Towards a revision of Cyclopinae copepods (Crustacea, Cyclopidae). Fragmenta Entomologica 28: 189-200.

Reid J.W. 1987. The cyclopoid copepods of a wet campo marsh in central Brazil. Hydrobiologia 153: 121-138. https://doi.org/10.1007/BF00006644

Reid J.W. 1991. The genus Metacyclops (Copepoda: Cyclopoida) present in North America: M. cushae, new species, from Louisiana. Journal of Crustacean Biology 11: 639-646. https://doi.org/10.2307/1548532

Rocha C.E.F. 1994. New species of Metacyclops (Copepoda, Cyclopidae) from Brazil, with remarks on M. campestris. Zoologica Scripta 23: 133-146. https://doi.org/10.1111/j.1463-6409.1994.tb00380.x

Sanoamuang L. 1999. Species composition and distribution of freshwater Calanoida and Cyclopoida (Copepoda) of Northeast Thailand. In: Schram F.R. \& von Vaupel Klein J.C. (eds) Crustaceans and the Biodiversity Crisis. Proceeding of the Fourth International Crustacean Congress, 1998. Vol.1:217-230. Brill, Leiden. 
Sanoamuang L. \& Watiroyram S. 2021. Description of Elaphoidella brancelji sp. nov. (Crustacea, Copepoda), a new species from a cave in Northern Thailand. Tropical Natural History 21: 321-336.

Sanoamuang L., Boonyanusith C. \& Brancelj A. 2019. A new genus and new species of stygobitic copepod (Crustacea: Copepoda: Cyclopoida) from Thien Duong Cave in Central Vietnam, with a redescription of Bryocyclops anninae (Menzel, 1926). Raffles Bulletin of Zoology 67: 189-205.

https://doi.org/10.26107/RBZ-2019-0016

Sket B. 2008. Can we agree on an ecological classification of subterranean animals? Journal of Natural History 42: 1549-1563. https://doi.org/10.1080/00222930801995762

Stoch F. 1987. Cave-dwelling cyclopoids (Crustacea, Copepoda) from Venezia Giulia (northeastern Italy). Bulletin Zoölogisch Museum 11: 41-56.

Tai A.Y. \& Chen G.X. 1979. Cyclopoida. In: Shen C.J. and Fauna Editorial Committee (eds) Fauna Sinica: Crustacea, Freshwater Copepoda: 301-420. Science Press, Beijing. [In Chinese.]

Tran D.L. \& Brancelj A. 2017. Amended diagnosis of the genus Nannodiaptomus (Copepoda, Calanoida), based on redescription of $N$. phongnhaensis and description of a new species from caves in central Vietnam. Zootaxa 4221: 457-476. https://doi.org/10.11646/zootaxa.4221.4.3

Watiroyram S. 2018a. Bryocyclops asetus sp. n. and the presence of Bryocyclops muscicola (Menzel, 1926) from Thailand (Crustacea, Copepoda, Cyclopoida, Cyclopidae). ZooKeys 793: 29-51.

https://doi.org/10.3897/zookeys.793.25005

Watiroyram S. 2018b. Two new species of the genus Bryocyclops Kiefer, 1927 (Copepoda: Cyclopoida: Cyclopidae) from southern Thailand. Raffles Bulletin of Zoology 66: 149-169.

Watiroyram S. 2021a. A new representative of the genus Bryocyclops Kiefer, 1927 from a karst cave in north-eastern Thailand (Copepoda, Cyclopoida, Cyclopidae) and comments on the generic affinities. Zoosystematics and Evolution 97: 97-109. https://doi.org/10.3897/zse.97.52354

Watiroyram S. 2021b. Attheyella (Canthosella) thailandica sp. nov. (Copepoda, Harpacticoida, Canthocamptidae) from caves in Thailand. Subterranean Biology 37: 57-73.

https://doi.org/10.3897/subtbiol.37.55376

Watiroyram S. \& Brancelj A. 2016. A new species of the genus Elaphoidella Chappuis (Copepoda, Harpacticoida) from a cave in the South of Thailand. Crustaceana 89: 459-476.

https://doi.org/10.1163/15685403-00003536

Watiroyram S., Brancelj A. \& Sanoamuang L. 2012. A new Bryocyclops Kiefer (Crustacea: Copepoda: Cyclopoida) from karstic caves in Thailand. Raffles Bulletin of Zoology 60: 11-21.

Watiroyram S., Brancelj A. \& Sanoamuang L. 2015a. A new cave-dwelling copepod from northeastern Thailand (Cyclopoida: Cyclopidae). Raffles Bulletin of Zoology 63: 426-437.

Watiroyram S., Brancelj A. \& Sanoamuang L. 2015b. Two new stygobiotic species of Elaphoidella (Crustacea: Copepoda: Harpacticoida) with comments on geographical distribution and ecology of harpacticoids from caves in Thailand. Zootaxa 3919: 81-99. https://doi.org/10.11646/zootaxa.3919.1.4

Watiroyram S., Sanoamuang L. \& Brancelj A. 2017. Two new species of Elaphoidella (Copepoda, Harpacticoida) from caves in southern Thailand and a key to the species of Southeast Asia. Zootaxa 4282: 501-525. https://doi.org/10.11646/zootaxa.4282.3.5

Watiroyram S., Sanoamuang L. \& Brancelj A. 2021. New species of Elaphoidella Chappuis, 1929 and Schizopera Sars, 1905 (Copepoda: Harpacticoida) from two caves in northeastern and southern Thailand. Zootaxa 5051: 550-569. https://doi.org/10.11646/zootaxa.5051.1.22 
Manuscript received: 8 June 2021

Manuscript accepted: 11 November 2021

Published on: 10 January 2022

Topic editor: Rudy C.A.M. Jocqué

Desk editor: Radka Rosenbaumová

Printed versions of all papers are also deposited in the libraries of the institutes that are members of the EJT consortium: Muséum national d'histoire naturelle, Paris, France; Meise Botanic Garden, Belgium; Royal Museum for Central Africa, Tervuren, Belgium; Royal Belgian Institute of Natural Sciences, Brussels, Belgium; Natural History Museum of Denmark, Copenhagen, Denmark; Naturalis Biodiversity Center, Leiden, the Netherlands; Museo Nacional de Ciencias Naturales-CSIC, Madrid, Spain; Real Jardín Botánico de Madrid CSIC, Spain; Zoological Research Museum Alexander Koenig, Bonn, Germany; National Museum, Prague, Czech Republic. 